\title{
Earthquake loss estimation for the Kathmandu Valley
}

\author{
Hemchandra Chaulagain ${ }^{1,2} \cdot$ Hugo Rodrigues $^{3}$ • \\ Vitor Silva $^{1} \cdot$ Enrico Spacone $^{4} \cdot$ Humberto Varum ${ }^{5}$
}

Received: 4 June 2014/Accepted: 4 September 2015/Published online: 15 September 2015

(C) Springer Science+Business Media Dordrecht 2015

\begin{abstract}
Kathmandu Valley is geologically located on lacustrine sediment basin, characterized by a long history of destructive earthquakes. The past events resulted in large structural damage, loss of human life's and property, and interrupted the social development. In recent years, the earthquake risk in this area has significantly increased due to uncontrolled development, poor construction practices with no earthquake safety provisions, and lack of awareness amongst the general public and government authorities. In this context, this study explores the realistic situation of earthquake losses due to future earthquakes in Kathmandu Valley. To this end, three municipalities: (a) Kathmandu Metropolitan City, (b) Lalitpur Sub-Metropolitan City and (c) Bhaktapur Municipality are selected for a case study. The earthquake loss estimation in the selected municipalities is performed through the combination of seismic hazard, structural vulnerability, and exposure data. Regarding the seismic input, various earthquakes scenario considering four seismic sources in Nepal are adopted. For what concerns the exposure, existing literature describing the construction typologies and data from the recent national census survey of 2011 are employed to estimate ward level distribution of buildings. The economic losses due to the earthquake scenarios are determined using fragility functions. Finally, the ward level distribution of building damage and the corresponding economic losses for each earthquake scenario is obtained using the OpenQuake-engine. The distribution of building damage within the Kathmandu Valley is currently being employed in the development of a shelter model for the region, involving various local authorities and decision makers.
\end{abstract}

Hugo Rodrigues

hugo.f.rodrigues@ipleiria.pt

1 RISCO - Civil Engineering Department, University of Aveiro, 3810-193 Aveiro, Portugal

2 Civil Engineering Department, Oxford College of Engineering and Management, Gaidakot, Nawalparashi, Nepal

3 RISCO - School of Technology and Management, Polytechnic Institute of Leiria, Leiria, Portugal

4 Department PRICOS - Architettura, University of Chieti-Pescara, 65127 Pescara, Italy

5 CONSTRUCT-LESE, Faculty of Engineering, University of Porto, 4200-465 Porto, Portugal 
Keywords Kathmandu Valley · Earthquake scenario - Ground motion fields · Fragility functions · Damage estimation

\section{Introduction}

Nepal is located in a seismically active region with a long history of devastating earthquakes. The main cause of earthquakes in Nepal is due to the subduction of the Indian plate underneath the Eurasian plate (Khattrai 1987). The major damaging earthquakes in Nepal took place in the years of 1255, 1408, 1681, 1803, 1810, 1833, 1934 and 1988 (Bilham et al. 1995; Pandey et al. 1995). As presented in Fig. 1, Nepal and the adjoining Himalayan arc has experienced some great historical earthquakes, including the 1897 Shillong earthquake, 1905 Kangara earthquake (Middlemiss 1910), 1934 Bihar-Nepal earthquake, and 1950 Assam earthquake. These seismic events evidently indicate that the entire Himalayan region is one of the most active zones in terms of seismic hazard. Recent research on fault modeling of Nepal Himalayan arc has also shown continuous accumulation of elastic strain to reactive older geological faults, which may generate earthquakes of strong magnitude (Chamlagain and Hayashi 2004, 2007).

The Kathmandu Valley is situated almost in the middle of Nepal, and is constituted by three administrative districts: Kathmandu, Lalitpur, and Bhaktapur. This region is composed by lacustrine sediments, which are considered to have high earthquake wave amplification capacity. The urbanization has been rapid throughout the Valley, and all of the urban settlements exhibit rapid growth around their periphery. Amongst the major earthquakes in recorded history, the Great Bihar-Nepal earthquake of 1934 with a maximum intensity of X (MMI) caused extensive damage in the Kathmandu Valley (Dunn et al. 1939; Pandey and Molnar 1988). The total death toll in Nepal was 8519, from which 4296 occurred in the Kathmandu Valley alone. In this earthquake, about $19 \%$ of the building stock collapsed and $38 \%$ experienced significant damage just in the Kathmandu Valley

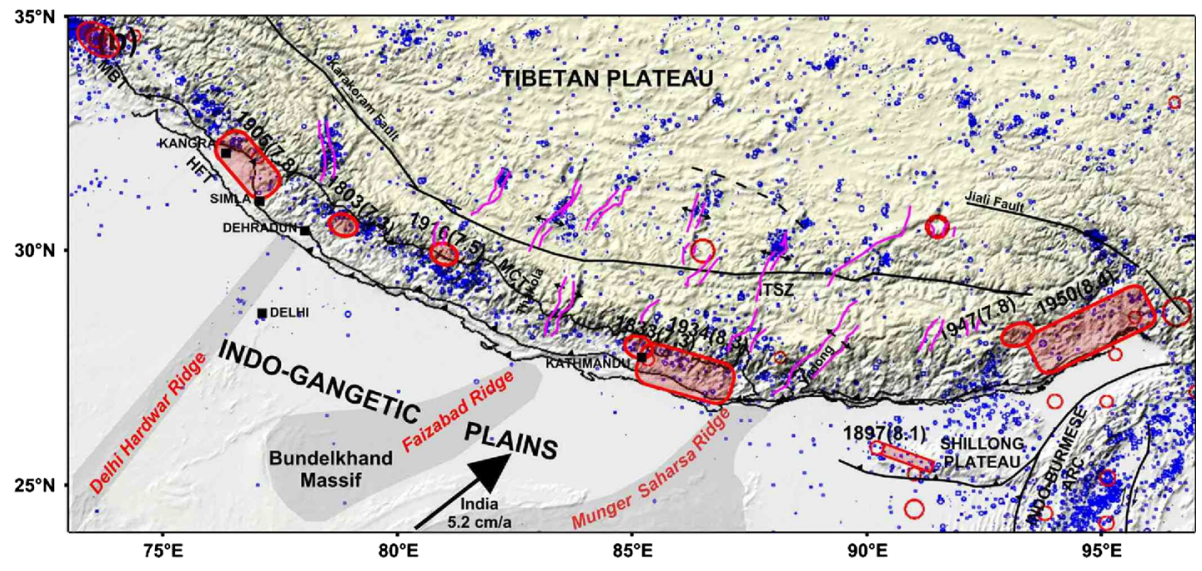

Fig. 1 Major tectonic features and seismicity in the Himalayan arc. The ruptures of earthquakes of $\mathrm{M}_{\mathrm{w}}>7.2$ of past 200 years in the Himalayan arc are shown by red rounded rectangles and ellipses. Earthquakes of $\mathrm{M}_{\mathrm{w}}>7>7.2$ are also shown by red circles (Gupta and Gahalaut 2014) 
(Pandey and Molnar 1988; Rana 1935). Furthermore, past studies showed that the human and economic losses due to earthquakes are directly related with the development index of a country (Erdik and Durukal 2008). The 1987 Loma Prieta earthquake (USA) caused only 62 deaths in the Bay Area, but the economic loss was estimated as $\$ 4.7$ billion. In a similar scale earthquake in Spitak (Armenia), over 20,000 people perished, but the economic loss was in the order of $\$ 570$ million (Chatelaine et al. 1999). As an underdeveloped country, earthquake consequences in Nepal might be more tragic than what was observed in Spitak.

In the background of aforementioned circumstances, this study explores the realistic situation of buildings damage and loss owing to the future earthquake scenarios. For this, the fragility functions used by the National Society for Earthquake Technology (NSET) are adopted for adobe (A), brick/stone buildings with mud mortar (BM/SM), brick/stone buildings with cement mortar (BC/SC), and wooden buildings (W), whilst new fragility functions are used for the reinforced concrete (RC) building types. For the development of new fragility function, three damage states (moderate damage, extensive damage, and collapse) are used to estimate the distribution of building damage. The static pushover to incremental dynamic analysis (SPO2IDA) tool is employed for the derivation of fragility functions. It provides a direct connection between the static pushover curve and the results of incremental dynamic analysis (Vamvatsikos and Cornell 2006). The results of the analysis are summarized into their 16, 50, and $84 \%$ fractile IDA curves. Furthermore, sets of fragility functions for each building type are converted into vulnerability functions through the employment of consequence models. In this process, the percentage of buildings in each damage state is computed at each intensity level, and multiplied by the respective damage ratio. These results can be used for seismic risk reduction or mitigation measures.

\subsection{Geo-tectonics and active faults in Nepal}

The Himalaya is as the result of a collision between the Indian plate in the south and the Eurasian plate in the north. This zone is significantly active and every year the Indian plate converges towards the north (relative to Eurasia). The territory of Nepal occupies the central sector of southwardly convex Himalayan mountain arc (i.e. $800 \mathrm{~km}$ out of a $2100 \mathrm{~km}$ long stretch). The active faults in and around Nepal Himalaya are classified into four groups: (a) the main central active fault system, (b) the active fault in lower Himalayas, (c) the main boundary active fault system, and (d) active faults along the Himalayan front fault (Nakata 1982). These are distributed mainly along the major tectonic elements as well as older geological faults. Among these, active faults along the Main Boundary Thrust (MBT) and Main Frontal Thrust (MFT) are most active and have potential to produce large earthquakes in the future (Lava and Avouac 2000; Chamlagain et al. 2000) (see Fig. 2). The general trend of distribution of seismicity consists of a narrow belt of predominantly moderate size earthquakes beneath the lesser Himalaya, just south of the Higher Himalayan front (Ni and Barazangi 1984), where all available fault-plane solution indicates thrusting. The great Himalayan earthquakes, however, occur along the basal detachment fault beneath the Siwalik and lesser Himalaya. The identification of the orientation of active faults brings the potential of assessing possible sources of future earthquakes. Hence, in this study, the selection of earthquake scenarios is also based on the active faults in and around the Himalayan region. 


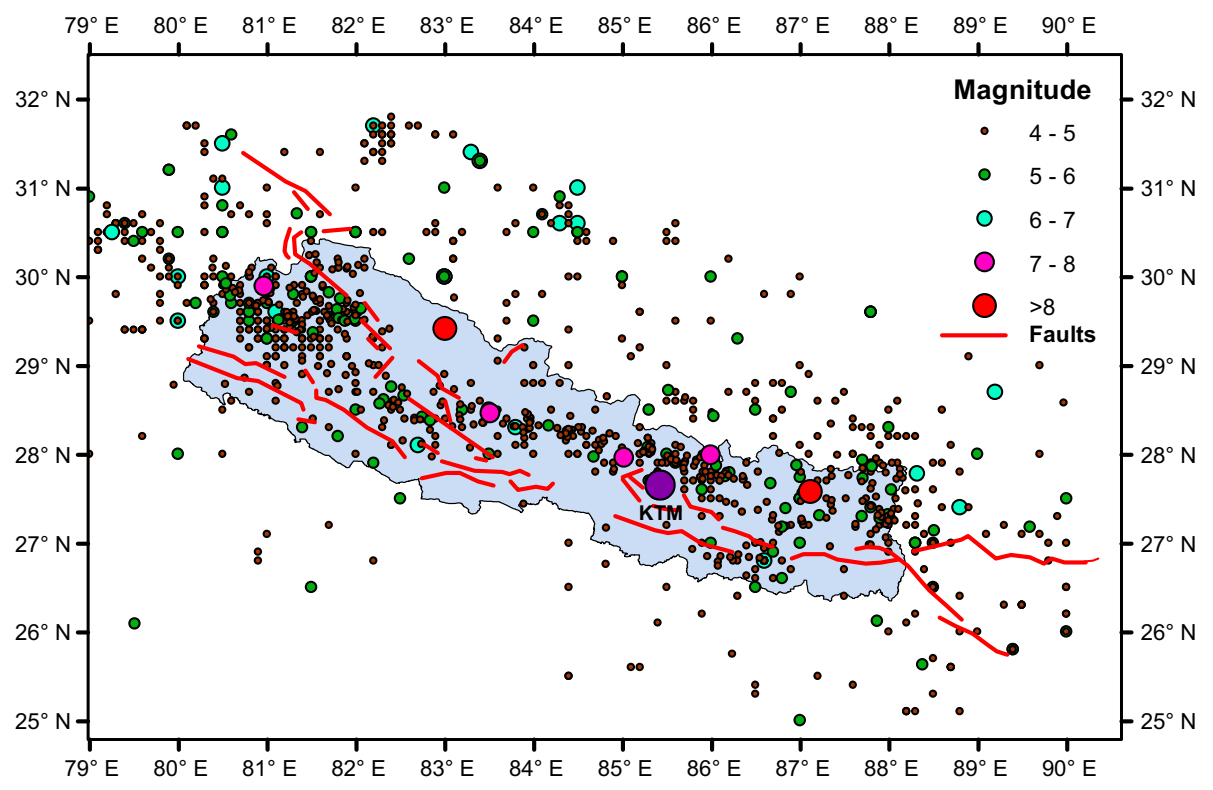

Fig. 2 Active faults in and around Nepal Himalaya

\subsection{Seismic gap and estimation of return period for great earthquakes in Himalaya}

The recurrences of historical earthquakes indicate that there is a gap between the two consecutive earthquakes in and around the location of Shillong, Kangara, Bihar-Nepal, and Assam. This region is known as the seismic gap, and is based on the concepts of plate tectonics and elastic rebound theory (Wyss and Wiemer 1999).

Researchers have identified the three main seismic gaps in the Himalayan arc: (a) Assam seismic gap, (b) Central seismic gap, and (c) Kashmir seismic gap. All these proposed seismic gaps along the entire Himalaya arc have the potential of generating large earthquakes. Khattri and Wyss (1978) proposed that the Assam gap extends in the region between the 1950 Assam and the 1897 Shillong earthquake ruptures. Similarly, the gap between the 1905 Kangara and the 1934 Bihar-Nepal earthquake is known as the Central gap (Sebber and Armbruster 1981). The Kashmir gap lies west of the 1905 Kangara earthquake rupture (Khattri and Wyss 1978). This region has not experience any great earthquake since 1555. Bilham (2001) applied the concept of the seismic gap in the Himalayan arc, and assumed that the seismogenic process is uniform throughout every segment of the Himalaya, and with a great potential to generate strong earthquakes. In particular, the regions lying in the aforementioned seismic gaps have accumulated slips of more than $8 \mathrm{~m}$ to be released in future events. The Kashmir, Central, and Assam gap regions have the potential to generate at least one, three, and two strong events, respectively (Bilham 2001). Furthermore, neotectonic, geomorphological, geophysical and seismological evidences also show that one or more mega-earthquakes may overdue in a large fraction in the Himalaya, threatening millions of people in the region. 


\section{Earthquake loss estimation}

\subsection{Earthquake scenarios}

The territory of Nepal spans about one-third of the length of the Himalayan arc. The Himalayan region has experienced at least five $M \sim 8\left(\mathrm{M}_{\mathrm{w}}\right)$ earthquakes during a seismically very active phase from 1897 through 1952 . However, there has not been a strong event since 1952. Satyabala and Gupta (1996) and Gupta and Gahalaut (2014) updated the magnitude distribution of earthquakes in the Himalayan region, as described in Table 1. They reported that there had been 14 major earthquakes of $\mathrm{M}_{\mathrm{w}} \geq 7.5$ during the period of 1897-1952.

Rupture length of an earthquake depends on the magnitude and location of the event. An earliest earthquake of magnitude $8.7\left(\mathrm{M}_{\mathrm{w}}\right)$ occurred in 12th June 1897 in Sillong Plateau demonstrate peak ground acceleration exceeding $1 \mathrm{~g}$. Past study shows that boulders were uplifted from the ground, buildings were damaged up to distance of $300 \mathrm{~km}$ from the epicenter whereas ground shaking was felt by humans up to a distance of $1500 \mathrm{~km}$ (Gutenberg and Richter 1954). A similar phenomenon was experienced in Kangara earthquake of magnitude $8.4\left(\mathrm{M}_{\mathrm{w}}\right)$ occurred in 4th April 1905, where rupture was observed within $300 \mathrm{~km}$ arc length.

Recently, Wallace et al. (2005) measured the part of the great Triangulation Survey network in the Kangara region by using GPS technology, and estimated a seismic slip of approximately $7 \mathrm{~m}$, and a rupture length of about $150 \mathrm{~km}$. An earthquake of magnitude of $8.3\left(\mathrm{M}_{\mathrm{w}}\right)$ occurred in 15th January of 1934 in Nepal, known as Bihar-Nepal earthquake. Ambraseys and Douglas (2004) evaluated the intensity of the 1934 Bihar-Nepal earthquake and found that most of the damage was actually concentrated in the Kathmandu Valley, with high MMI intensity reaching $X$. The earthquake rupture was confined in the Himalayan with a length of about 200-300 km and slip of $6 \mathrm{~m}$ (Molnar and Pandey 1988). The latest great earthquake with a magnitude $\left(\mathrm{M}_{\mathrm{w}}\right)$ of 8.6 occurred in the Himalaya in 15th of August of 1950. The inferred dimension of rupture zone was about $250 \mathrm{~km}$ in east-west dimension and $100 \mathrm{~km}$ in the north-south direction (Molnar and Pandey 1988). The earthquake occurred in the 8th October 2005 was the most damaging earthquake, ever occurred in the Himalaya in the last two centuries. The magnitude $7.6\left(\mathrm{M}_{\mathrm{w}}\right) \mathrm{Kashmir}$ earthquake killed more than 80,000 people. The earthquake occurred through a thrust motion on a $75 \mathrm{~km}$ fault in the Indo-Kohistan seismic zone with a maximum surface offset of about $7 \mathrm{~m}$. The rupture was steep (with a dip of about $20^{\circ}$ ) in comparison to other moderate and major Himalayan earthquakes. All these events occurred in an interval of about 50 years in the Himalaya and adjoining regions (see Fig. 1).

Regarding the earthquakes in and around Nepal, the epicentral distribution map indicates that seismicity is active in the western and eastern part of Nepal. The central part of Nepal has suffered relatively few earthquakes (Pandey et al. 1999). Figure 2 shows that a belt of seismicity that follows approximately the front of the Higher Himalaya with most of

Table 1 Magnitude distribution of earthquakes in the Himalayan region

\begin{tabular}{llc}
\hline Magnitude & $1897-1952$ & $1953-2011$ \\
\hline$M \geq 7.5$ & 14 & 2 \\
$7.5>M \geq 7.0$ & 11 & 9 \\
$7.0>M \geq 6.5$ & 19 & 27 \\
\hline
\end{tabular}


the seismic moment being released at depths between 10 and $20 \mathrm{~km}$. The seismic activity is more intense around $82^{\circ} \mathrm{E}$ in Far-Western Nepal and around $87^{\circ} \mathrm{E}$ in Eastern Nepal. Western Nepal between 85.5 and $85^{\circ} \mathrm{E}$ is characterized by particular low level of seismic activity. The central Himalayan region of Nepal has not been active during this period. Pandey et al. (1999) describe four long segments $(250-400 \mathrm{~km})$ that could produce earthquakes comparable to the $\mathrm{M}=8.3\left(\mathrm{M}_{\mathrm{w}}\right)$ Bihar-Nepal earthquake that struck eastern Nepal in 1934.

In this context, earthquakes scenario 1,2 and 3 are selected considering past studies, orientation of active faults and seismicity in and around Nepal Himalaya, while earthquake scenario 4 is based on the recurrence of historical event (1934 Bihar-Nepal earthquake). The characteristics of the earthquakes scenario are presented in Table 2. The vertical projections of the fault rupture for the four events are shown in Fig. 3.

\subsection{Characteristics of the building stock in Kathmandu Valley}

The buildings in the Kathmandu Valley were characterized during the National Population and Housing Census in 2011 (CBS 2012). The information obtained from the National Census Report includes: type of foundation, outer wall and roof of the house. The distribution of building structures in Nepal and location within the Kathmandu Metropolitan

Table 2 Characteristics of earthquake scenarios in Nepal

\begin{tabular}{|c|c|c|c|c|c|c|c|c|}
\hline \multirow{3}{*}{$\begin{array}{l}\text { S. no. } \\
1\end{array}$} & \multirow{3}{*}{$\begin{array}{l}\text { Scenario EQ } \\
\text { EQ1 }\end{array}$} & \multirow{3}{*}{$\begin{array}{l}\text { Magnitude }\left(\mathrm{M}_{\mathrm{w}}\right) \\
6.0\end{array}$} & \multirow{2}{*}{\multicolumn{2}{|c|}{ Hypocenter }} & \multicolumn{4}{|c|}{ Fault trace } \\
\hline & & & & & \multicolumn{2}{|c|}{ Fault coordinate 1} & \multicolumn{2}{|c|}{ Fault coordinate 2} \\
\hline & & & 28.08 & 85.17 & 27.929 & 85.288 & 28.244 & 85.050 \\
\hline 2 & EQ2 & 7.0 & 27.00 & 85.48 & 27.263 & 84.551 & 26.751 & 86.407 \\
\hline 3 & EQ3 & 8.0 & 28.42 & 82.93 & 27.816 & 83.664 & 29.018 & 82.225 \\
\hline 4 & EQ4 & 8.2 & 27.56 & 87.07 & 27.757 & 85.958 & 27.365 & 88.183 \\
\hline
\end{tabular}

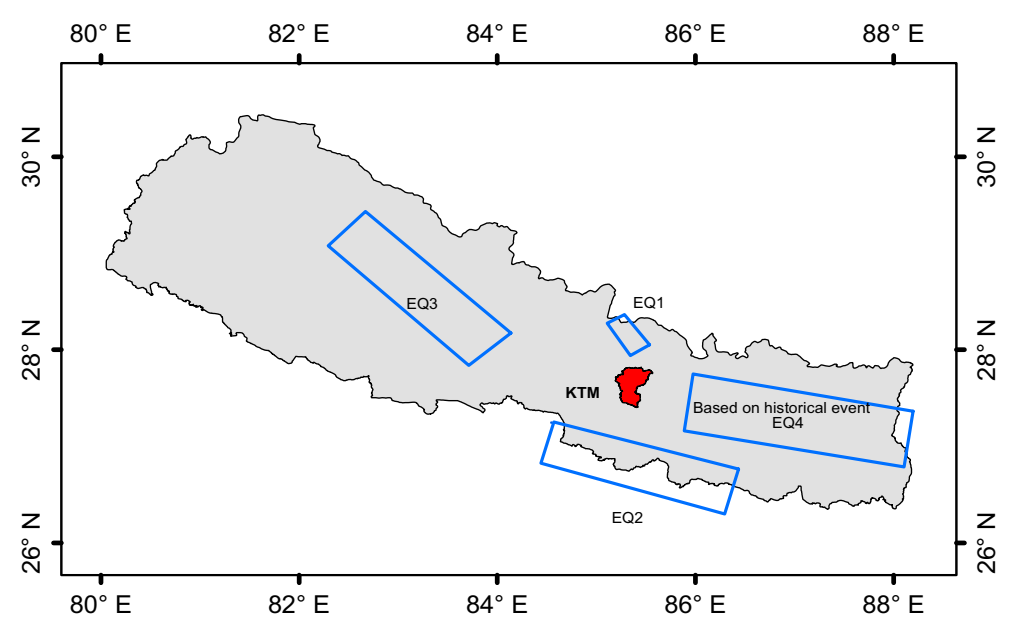

Fig. 3 Location of vertical project of the fault ruptures surfaces for the four earthquake scenarios in Nepal 


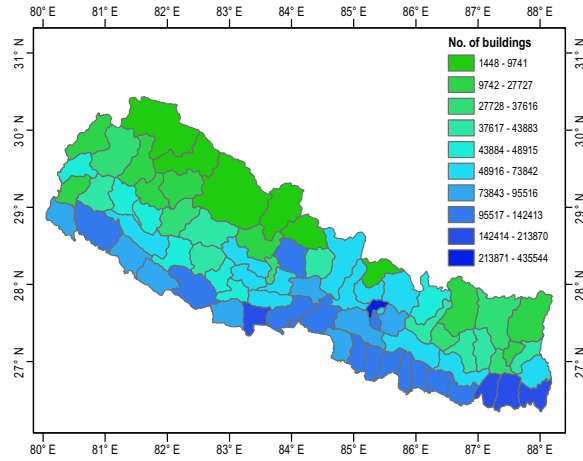

(a)

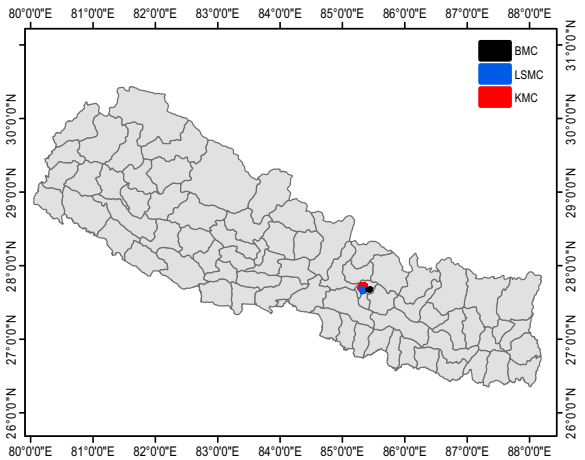

(b)

Fig. 4 a Distribution of buildings in Nepal and b Location of case study Municipalities in Kathmandu Valley

Table 3 Distribution of building according to the building taxonomy in the Kathmandu Metropolitan City, Lalitpur Sub-Metropolitan City, and Bhaktapur Municipality

\begin{tabular}{lrrrrrrr}
\hline Location & A & BM/SM & BC/SC & CCP & NBC & NBC+ & WDS \\
\hline BMC & 531 & 5468 & 4761 & 5229 & 551 & 551 & 551 \\
LSMC & 1635 & 14,739 & 16,374 & 16,593 & 1746 & 1746 & 1746 \\
KMC & 4629 & 59,807 & 89,699 & 76,144 & 8013 & 8013 & 8013 \\
\hline
\end{tabular}

City (KMC), Lalitpur Sub-Metropolitan City (LSMC) and Bhaktapur Municipality (BMC) are presented in Fig. 4. The distribution of building according to the building taxonomy in the aforementioned municipalities is presented in Table 3. The census survey data indicates that mud bonded bricks/stones (BM/SM), cement bonded bricks/stones (BC/SC), and reinforced concrete (RC) buildings are the most common building typologies in the Kathmandu Valley. In this study, the mixed buildings like stone and adobe, stone and brick in mud, brick in mud and brick in cement are considered as a single typology adobe (A), since their structural vulnerability is identical. Four types of reinforced concrete buildings are considered in the present study. The first type corresponds to a moment resisting frame designed according to the current construction practices in Nepal (CCP structure); the second design type is based on Nepal Building Code based on Mandatory Rules of Thumb (NBC structure); the third type of structure follows a modified version of the Nepal Building Code (NBC+ structure) and the last type of $\mathrm{RC}$ frame represent the moment resisting frames which are designed based on the Indian standard code, which contains adequate seismic provisions (Well Designed Structures-WDS) (Chaulagain et al. 2013). The detailing of Nepalese RC buildings will be discussed in Sect. 2.2.1. A description of each building typology is summarized in Table 4. The distribution of buildings in a case study municipalities are shown in Fig. 5.

\subsubsection{Detailing of RC building structures}

The beam reinforcement quantity at the support and mid-span for the WDS, NBC+, NBC, and CCP structures are presented in Table 5. The CCP structure uses the same amount of 
Table 4 Buildings types in Kathmandu Valley

\begin{tabular}{ll}
\hline Building & Description \\
\hline Adobe & $\begin{array}{l}\text { These are buildings constructed in sun-dried bricks } \\
\text { (earthen) with mud mortar for the construction of } \\
\text { structural walls. The wall thickness is usually more } \\
\text { than } 350 \mathrm{~mm}\end{array}$
\end{tabular}

Brick in mud mortar

Stone in mud mortar

Brick in cement mortar

Stone in cement mortar

Current construction practices

Nepal Building Code recommendation

Modified Nepal Building Code recommendation
These are the low strength masonry buildings. The brick in mud mortar buildings are made of fired bricks in mud mortar. This type of building generally has flexible floors and roof

The stone in mud mortar buildings are constructed using dressed or undressed stones with mud mortar. These types of buildings generally have flexible floors and roof

Photo
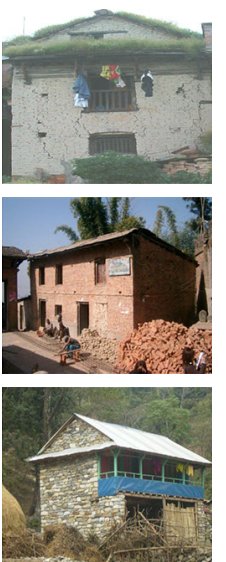

With the advancement of the cement in Nepal, brick masonry buildings with mud mortar are replaced by the cement mortar. These buildings are constructed with fired bricks in cement or lime mortar

The stone in cement mortar buildings are constructed using dressed or undressed stones with cement mortar

These are buildings with RC frames and unreinforced brick masonry infill in cement mortar. The thickness of the infill walls is $230 \mathrm{~mm}$ or $115 \mathrm{~mm}$, and the column size is predominantly $230 \mathrm{~mm} \times 230 \mathrm{~mm}$. These buildings are not properly designed and their construction is not supervised by engineers

The NBC structure is designed with the Mandatory Rules of Thumb (MRT). MRT provides some readyto-use provisions in terms of dimensions and details for structural and non-structural elements for up to three storeys (NBC 205 1994)

In 2010, the Department of Urban Development and Building Construction published additional recommendations for the construction of Earthquake Safer Buildings in Nepal with the assistance of UNDP (UNDP 2010). This document is an improvement of the NBC. The RC buildings which are designed considering these improvements are called NBC+ structures
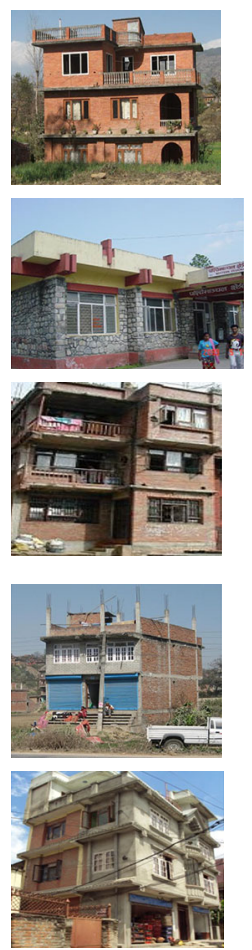
Table 4 continued

\begin{tabular}{|c|c|c|}
\hline Building & Description & Photo \\
\hline Well designed structures & $\begin{array}{l}\text { The WDS buildings are designed considering seismic } \\
\text { provisions with ductile detailing located in seismic } \\
\text { zone V (regions liable to shaking intensities of IX and } \\
\text { higher) and medium soil. Seismic analyses are } \\
\text { performed using the seismic coefficient method (IS } \\
18932002 \text { ) and the detailed design of the beams and } \\
\text { column sections are performed according to the IS } \\
13920 \text { (1993) recommendations }\end{array}$ & 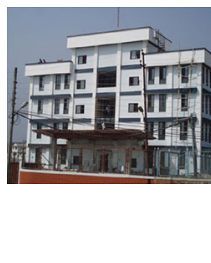 \\
\hline
\end{tabular}

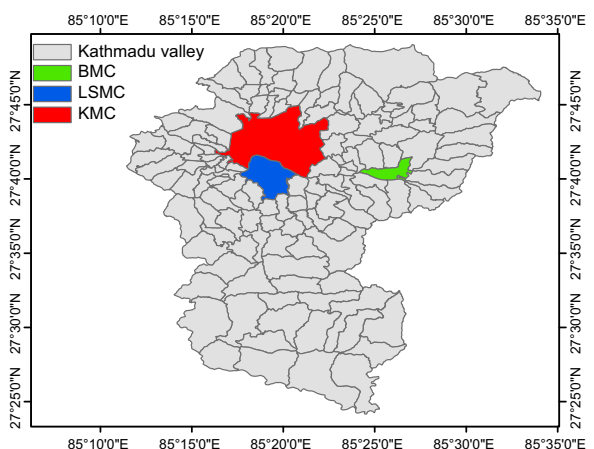

(a)

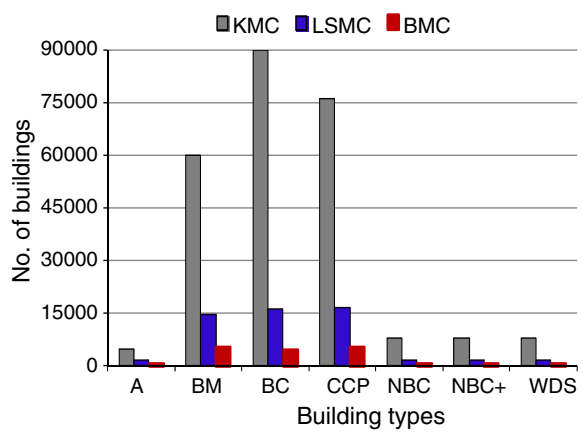

(b)

Fig. 5 a Location of Kathmandu Metropolitan City (KMC), Lalitpur Sub-Metropolitan City (LSMC) and Bhaktapur Municipality (BMC) and b Number of building typologies in KMC, LSMC and BMC

reinforcement for negative and positive bending moments throughout the entire span of the beam. This amount is the lowest among all structures. There is a clear improvement in the beam detailing of the NBC and NBC+ structures. In these structures, the amount of support reinforcement is relatively larger than the CCP structure. Moreover, in NBC and $\mathrm{NBC}+$ structures more reinforcement is provided in the first and second storey beams compared to top floor beam. In contrast, as expected, the WDS structure demands more reinforcement to withstand ground shaking.

The provisions of the columns and its reinforcement in the corners, the façade and the interior columns in the study building structures are presented in Table 6. The CCP structure uses the same column size of $230 \mathrm{~mm} \times 230 \mathrm{~mm}$ with the same amount of reinforcement in every column. There are some improvements in the size and reinforcement amount in the corner, façade and interior columns in the NBC structures. A larger size of columns $(270 \mathrm{~mm} \times 270 \mathrm{~mm})$ is used in the first storey and the same smaller size of columns $(230 \mathrm{~mm} \times 230 \mathrm{~mm})$ is used in the second and third storeys. In the NBC+ structure, a minimum size of $300 \mathrm{~mm} \times 300 \mathrm{~mm}$ column is used for the whole structure. In contrast, as expected, the WDS structure demands more reinforcement with larger column sizes to withstand the expected ground shaking. This amount is significantly higher than $\mathrm{CCP}, \mathrm{NBC}$ and $\mathrm{NBC}+$ structures. 
Table 5 Longitudinal reinforcement of beam sections $(230 \mathrm{~mm} \times 325 \mathrm{~mm})$

\begin{tabular}{|c|c|c|c|c|c|c|c|}
\hline \multirow[t]{2}{*}{ Beam } & \multirow[t]{2}{*}{ Storey } & \multicolumn{3}{|c|}{ At support } & \multicolumn{3}{|c|}{ At mid-span } \\
\hline & & WDS & $\mathrm{NBC} / \mathrm{NBC}+$ & $\mathrm{CCP}$ & WDS & $\mathrm{NBC} / \mathrm{NBC}+$ & $\mathrm{CCP}$ \\
\hline & $1 \mathrm{st}$ & $\frac{6 \emptyset 16}{3 \emptyset 16}$ & $\frac{2 \emptyset 16+2 \emptyset 12}{2 \emptyset 16+2 \emptyset 12}$ & $\frac{3 \emptyset 12}{3 \emptyset 12}$ & $\frac{2 \emptyset 16}{3 \emptyset 16}$ & $\frac{2 \emptyset 16}{2 \emptyset 16}$ & $\frac{2 \emptyset 12}{2 \emptyset 12}$ \\
\hline & $2 \mathrm{nd}$ & $\frac{6 \emptyset 16}{3 \emptyset 16}$ & $\frac{2 \emptyset 16+2 \emptyset 12}{2 \emptyset 16+2 \emptyset 10}$ & $\frac{3 \emptyset 12}{3 \emptyset 12}$ & $\frac{2 \emptyset 16}{3 \emptyset 16}$ & $\frac{2 \emptyset 16}{2 \emptyset 16}$ & $\frac{2 \emptyset 12}{2 \emptyset 12}$ \\
\hline & $3 \mathrm{rd}$ & $\frac{3 \emptyset 16}{2 \emptyset 16}$ & $\frac{3 \emptyset 12}{3 \emptyset 12}$ & $\frac{2 \emptyset 12}{2 \emptyset 12}$ & $\frac{2 \emptyset 16}{2 \emptyset 16}$ & $\frac{2 \emptyset 12}{2 \emptyset 12}$ & $\frac{2 \emptyset 12}{2 \emptyset 12}$ \\
\hline & $1 \mathrm{st}$ & $\frac{5 \emptyset 16}{4 \emptyset 16}$ & $\frac{3 \emptyset 16}{3 \emptyset 16}$ & $\frac{3 \emptyset 12}{3 \emptyset 12}$ & $\frac{2 \emptyset 16}{2 \emptyset 16}$ & $\frac{2 \emptyset 16}{2 \emptyset 16}$ & $\frac{2 \emptyset 12}{2 \emptyset 12}$ \\
\hline & 2 nd & $\frac{5 \emptyset 16}{4 \emptyset 16}$ & $\frac{2 \emptyset 16+2 \emptyset 12}{2 \emptyset 16+2 \emptyset 12}$ & $\frac{3 \emptyset 12}{3 \emptyset 12}$ & $\frac{2 \emptyset 16}{2 \emptyset 16}$ & $\frac{2 \emptyset 16}{2 \emptyset 16}$ & $\frac{2 \emptyset 12}{2 \emptyset 12}$ \\
\hline & $3 \mathrm{rd}$ & $\frac{3 \emptyset 16}{2 \emptyset 16}$ & $\frac{3 \emptyset 12}{3 \emptyset 12}$ & $\frac{2 \emptyset 12}{2 \emptyset 12}$ & $\frac{2 \emptyset 16}{2 \emptyset 16}$ & $\frac{2 \emptyset 12}{2 \emptyset 12}$ & $\frac{2 \emptyset 12}{2 \emptyset 12}$ \\
\hline & $1 \mathrm{st}$ & $\frac{5 \emptyset 16}{3 \emptyset 16}$ & $\frac{3 \emptyset 16}{3 \emptyset 16}$ & $\frac{3 \emptyset 12}{3 \emptyset 12}$ & $\frac{2 \emptyset 16}{2 \emptyset 16}$ & $\frac{2 \emptyset 12}{2 \emptyset 12}$ & $\frac{2 \emptyset 12}{2 \emptyset 12}$ \\
\hline & 2nd & $\frac{5 \emptyset 16}{3 \emptyset 16}$ & $\frac{2 \emptyset 16+1 \emptyset 12}{2 \emptyset 16+1 \emptyset 12}$ & $\frac{3 \emptyset 12}{3 \emptyset 12}$ & $\frac{2 \emptyset 16}{2 \emptyset 16}$ & $\frac{2 \emptyset 12}{2 \emptyset 12}$ & $\frac{2 \emptyset 12}{2 \emptyset 12}$ \\
\hline & $3 \mathrm{rd}$ & $\frac{2 \emptyset 16}{2 \emptyset 16}$ & $\frac{3 \emptyset 12}{3 \emptyset 12}$ & $\frac{2 \emptyset 12}{2 \emptyset 12}$ & $\frac{2 \emptyset 16}{2 \emptyset 16}$ & $\frac{2 \emptyset 12}{2 \emptyset 12}$ & $\frac{2 \emptyset 12}{2 \emptyset 12}$ \\
\hline
\end{tabular}

Table 6 Longitudinal reinforcement and dimension of column cross-sections (all dimensions are in $\mathrm{mm}$ )

\begin{tabular}{|c|c|c|c|c|c|}
\hline \multirow[t]{2}{*}{ Column } & \multirow[t]{2}{*}{ Storey } & \multicolumn{4}{|c|}{ Cross section of column } \\
\hline & & WDS & $\mathrm{NBC}+$ & NBC & $\mathrm{CCP}$ \\
\hline & $1 \mathrm{st}$ & $\begin{array}{l}8 \emptyset 16 \\
300 \times 300\end{array}$ & $\begin{array}{l}4 \emptyset 16 \\
300 \times 300\end{array}$ & $\begin{array}{l}4 \emptyset 16 \\
270 \times 270\end{array}$ & $\begin{array}{l}4 \emptyset 16 \\
230 \times 230\end{array}$ \\
\hline & 2nd & $\begin{array}{l}8 \emptyset 16 \\
300 \times 300\end{array}$ & $\begin{array}{l}4 \emptyset 16 \\
300 \times 300\end{array}$ & $\begin{array}{l}4 \emptyset 16 \\
230 \times 230\end{array}$ & $\begin{array}{l}4 \emptyset 16 \\
230 \times 230\end{array}$ \\
\hline & $3 \mathrm{rd}$ & $\begin{array}{l}8 \emptyset 16 \\
300 \times 300\end{array}$ & $\begin{array}{l}4 \emptyset 16 \\
300 \times 300\end{array}$ & $\begin{array}{l}4 \emptyset 12 \\
230 \times 230\end{array}$ & $\begin{array}{l}4 \emptyset 16 \\
230 \times 230\end{array}$ \\
\hline & $1 \mathrm{st}$ & $\begin{array}{l}8 \emptyset 16 \\
350 \times 350\end{array}$ & $\begin{array}{l}4 \emptyset 16 \\
300 \times 300\end{array}$ & $\begin{array}{l}4 \emptyset 16 \\
270 \times 270\end{array}$ & $\begin{array}{l}4 \emptyset 16 \\
230 \times 230\end{array}$ \\
\hline & 2 nd & $\begin{array}{l}8 \emptyset 16 \\
350 \times 350\end{array}$ & $\begin{array}{l}4 \emptyset 16 \\
300 \times 300\end{array}$ & $\begin{array}{l}4 \emptyset 16 \\
230 \times 230\end{array}$ & $\begin{array}{l}4 \emptyset 16 \\
230 \times 230\end{array}$ \\
\hline & $3 \mathrm{rd}$ & $\begin{array}{l}8 \emptyset 16 \\
300 \times 300\end{array}$ & $\begin{array}{l}4 \emptyset 16 \\
300 \times 300\end{array}$ & $\begin{array}{l}4 \emptyset 12 \\
230 \times 230\end{array}$ & $\begin{array}{l}4 \emptyset 16 \\
230 \times 230\end{array}$ \\
\hline & $1 \mathrm{st}$ & $\begin{array}{l}8 \emptyset 16 \\
350 \times 350\end{array}$ & $\begin{array}{l}8 \emptyset 12 \\
300 \times 300\end{array}$ & $\begin{array}{l}8 \emptyset 12 \\
270 \times 270\end{array}$ & $\begin{array}{l}4 \emptyset 16 \\
230 \times 230\end{array}$ \\
\hline$\ldots$ & 2nd & $\begin{array}{l}8 \emptyset 16 \\
350 \times 350\end{array}$ & $\begin{array}{l}8 \emptyset 12 \\
300 \times 300\end{array}$ & $\begin{array}{l}8 \emptyset 12 \\
230 \times 230\end{array}$ & $\begin{array}{l}4 \emptyset 16 \\
230 \times 230\end{array}$ \\
\hline & $3 \mathrm{rd}$ & $\begin{array}{l}8 \emptyset 16 \\
300 \times 300\end{array}$ & $\begin{array}{l}8 \emptyset 12 \\
300 \times 300\end{array}$ & $\begin{array}{l}4 \emptyset 12 \\
230 \times 230\end{array}$ & $\begin{array}{l}4 \emptyset 16 \\
230 \times 230\end{array}$ \\
\hline
\end{tabular}

\subsection{Development of exposure model}

For the development of exposure model, a new set of building classes have been defined to distinguish each construction type according to its seismic vulnerability. As discussed in Sect. 2.2, adobe, mud bonded brick, mud bonded cement, cement bonded brick, cement 
bonded stone and RC buildings are the most common typologies in the Kathmandu Metropolitan City, Lalitpur Sub-Metropolitan City and Bhaktapur Municipality. For the sake of simplicity, the vulnerability of buildings classified as mixed and other not stated categories in the national census survey are considered to have a similar performance as adobe. The fractions of CCP, NBC, NBC+, and WDS structures are considered as 76, 8, 8 and $8 \%$, respectively (Dixit 2004; Shrestha and Dixit 2008). Considering the classification of buildings and their respective volume described in Table 7, a ward level exposure model containing the number of buildings from each vulnerability class was created. The vulnerability class and its corresponding volume is based on the results presented in JICA (2002), CBS (2012) and Chaulagain et al. (2013). For the purpose of computing the seismic hazard at each asset location, it was assumed that all of the buildings are equally distributed within the whole ward, which is a common assumption when performing seismic risk assessment at a large scale (e.g. Bommer et al. 2002; Crowley et al. 2008; Silva et al. 2014a).

\subsubsection{Estimation of economic value}

The spatial distribution of building count is a fundamental component for earthquake scenario damage assessment, which can then be used to create post-disaster emergency plans or to design risk mitigation strategies. However, in order to estimate the associated economic losses, it is necessary to attribute a building cost to each typology. In the present study, the building cost is established as the required monetary value to construct a building with the same characteristics according to the current costs, herein termed as the replacement cost. This value naturally depends on the location and total area of the buildings. Due to the location of similar geographical region, the same building cost is applied to all the studied municipalities. Table 8 presents the construction type, area per building type and corresponding construction cost for the buildings in Kathmandu Valley.

\subsection{Development of the vulnerability model}

In this section, an analytical methodology that uses non-linear analysis to calculate a fragility model is described. Afterwards, these results are converted into a vulnerability model through the employment of a consequence model. The damage state criteria, procedure to generate the fragility model, and the consequence model employed to convert fragility curves into vulnerability curves are important to derive vulnerability functions.

Table 7 Vulnerability classes for building stock in Kathmandu Metropolitan City, Lalitpur SubMetropolitan City, and Bhaktapur Municipality

\begin{tabular}{llll}
\hline $\begin{array}{l}\text { Building } \\
\text { types }\end{array}$ & \% of buildings & & \\
\cline { 2 - 4 } & $\begin{array}{l}\text { Kathmandu } \\
\text { Metropolitan City }\end{array}$ & $\begin{array}{l}\text { Lalitpur Sub- } \\
\text { Metropolitan City }\end{array}$ & $\begin{array}{l}\text { Bhaktapur } \\
\text { Municipality }\end{array}$ \\
\hline A & 2 & 3 & 3 \\
BM/SM & 26 & 27 & 31 \\
BC/SC & 33 & 30 & 27 \\
CCP & 30 & 31 & 30 \\
NBC & 3 & 3 & 3 \\
NBC + & 3 & 3 & 3 \\
WDS & 3 & 3 & 3 \\
\hline
\end{tabular}


Table 8 Area and corresponding construction cost of existing buildings in Kathmandu Valley

\begin{tabular}{lll}
\hline Construction type & $\begin{array}{l}\text { Area per } \\
\text { building }\left(\mathrm{m}^{2}\right)\end{array}$ & $\begin{array}{l}\text { Construction } \\
\operatorname{cost}\left(€ / \mathrm{m}^{2}\right)\end{array}$ \\
\hline A & 60 & 150 \\
BM/SM & 70 & 225 \\
BC/SC & 80 & 275 \\
CCP & 80 & 300 \\
NBC & 80 & 325 \\
NBC + & 80 & 350 \\
WDS & 90 & 375 \\
\hline
\end{tabular}

The assumptions and main results from each of the aforementioned components are further discussed in the following sub-sections.

\subsubsection{Damage state criteria}

The performance levels of a building can be defined through damage thresholds called limit states. A limit state defines the threshold between different damage conditions, whereas the damage state defines the damage conditions themselves. The number of the damage states depends on the damage scale used. Some of the most frequently damage scales used are: HAZUS99 (FEMA 1999), ATC-13 (ATC 1985), Vision 2000 (SEAOC 1995) and EMS-98 (Grünthal 1998). The last one, commonly used in Europe, was used in the study of Rota et al. (2008) and Gaspari (2009). Dumova-Jovanoska (2000) used damage indices to classify damage into five grades: none, minor, moderate, severe and collapse. Rosetto and Elnashai (2005) used the inter-storey drift to classify damage in seven grades: none, slight, light, moderate, extensive, partial collapse, and collapse. Kircil and Polat (2006) used damage states of yielding and collapse for performance assessment of structures. A global parameter such as maximum global drift (Akkar et al. 2005) or maximum inter-storey drift (Hancilar et al. 2006; Rosetto and Elnashai 2005) was preferred in this study. For the estimation of the global drift limits, a displacement-based adaptive pushover curve (Antoniou and Pinho 2004) was derived for each RC buildings without the masonry infills (bare frame), and three limit state global drifts were extracted based on the following criteria.

Moderate damage: global drift when $0.5 \%$ of the maximum inter-storey drift is achieved;

Extensive damage: global drift when $1.5 \%$ of maximum inter-storey drift is achieved; Collapse: global drift when $2.5 \%$ of maximum inter-storey drift is achieved.

\subsubsection{Fragility model for Nepalese RC buildings}

The vulnerability conditions of the building can be described using vulnerability or fragility functions. Vulnerability functions describe the probability of fraction of loss given a level of ground shaking, whilst fragility functions provide the probability of exceeding different damage states for a set of levels of ground shaking. Currently, there is no consensus regarding the derivation of fragility models. Different methods can be organized in: (i) empirical method, (ii) expert opinion-based method, (iii) analytical method and (iv) hybrid method. 
Empirical fragility curves are constructed on statistics of the observed damage from past earthquakes, such as from data collected through post-earthquake surveys (Colombi et al. 2008). Expert opinion-based fragility curves depend on the judgment and the information of the experts. The experts are asked to provide an estimate of the probability of damage for different types of structures and several levels of ground shaking (Kostov et al. 2007). Hybrid fragility curves are based on the combination of different methods for damage prediction. The aim of this method is to compensate for the lack of observational data, the deficiencies of the structural models and the subjectivity in expert opinion data (Barbat et al. 1996; Kappos et al. 2006). Analytical fragility curves are derived based on the characteristics of the building stock and hazard by analyzing the structural models under increasing earthquake intensity. Non-linear static or dynamic analyses are used in this procedure. Akkar et al. (2005), Erberic and Elnashai (2004), Kircil and Polat (2006) and Silva et al. (2014b) are some examples of studies based on analytical methods. There is a high degree of uncertainty while drawing the fragility curve, due to the record-to-record variability, the analytical methodology, the uncertainty in the materials and geometric properties and the definition of the damage states.

In the present study, for the earthquake loss estimation of the cities in the Kathmandu Valley, the commonly used standard fragility functions [the fragility functions commonly applied by the National Society for Earthquake Technology (NSET), Nepal] and the new fragility model analytically developed in this study are used. To this end, the structural models for RC buildings are created considering the geometrical and material properties of Nepalese RC buildings (Chaulagain et al. 2013). The SPO2IDA framework developed by Vamvatsikos and Cornell (2006) was employed to convert static pushover curves into incremental dynamic analysis. SPO2IDA represents a tool that is capable of recreating the seismic behavior of oscillators with complex multi-linear backbones at almost any period. It provides a direct connection between the static pushover curve and the results of incremental dynamic analysis, a computer-intensive procedure that offers thorough (demand and capacity) prediction by using a series of non-linear dynamic analyses under a suitably scaled suite of ground motion records. The results of the analysis are summarized into their 16, 50, and $84 \%$ fractile IDA curves. It offers effectively instantaneous estimation of demands and limit-state capacities, in addition to conventional strength reduction R-factor and inelastic displacement ratios, for any SDOF whose SPO curve can be approximated by a quadrilinear backbone. The construction process of a fragility function consists of the following steps:

Step 1 Development of an appropriate numerical model of the selected structure for nonlinear analysis.

The computer program SeismoSoft (2006) was used, adopting a lumped plasticity model for the RC frame elements. The numerical analysis is based on bare frame building modelling with three-dimensional models. In modelling, half of the larger dimension of the cross-section is considered as the plastic hinge length with fibre discretisation at the section level.

The concrete model is based on the Madas and Elnashai (1992) uniaxial model, which follows the constitutive law proposed by Mander et al. (1988). The cyclic rules included in the model for the confined and unconfined concrete according with Martinez-Rueda (1997) and Elnashai and Elghazouli (1993) proposal. The confinement effects provided by the transverse reinforcement were considered through the rules proposed by Mander et al. (1988), whereby constant confining pressure is assumed throughout the entire stress-strain 
range, traduced by the increase in the peak value of the compression strength and the stiffness of the unloading branch.

The uniaxial model proposed by Menegotto and Pinto (1973), coupled with the isotropic hardening rules proposed by Filippou et al. (1983), was adopted to model the behavior of the reinforcement steel. This steel model does not represent the yielding plateau characteristic of the mild steel virgin curve. The model takes into account the Bauschinger effect, which is relevant for the representation of the columns' stiffness degradation under cyclic loading. An example of the 3D model adopted for non-linear analysis in this study is presented in Fig. 6.

Step 2 Perform non-linear static analyses to identify the sequence of simulated and nonsimulated failure for the each principal building direction.

Adaptive pushover analyses were employed in the estimation of the capacity of a structure, taking full account of the effect that the deformation of the structure and the frequency content of input motion have on its dynamic response characteristic (Antoniou and Pinho 2006). The lateral load distribution is not kept constant but rather continuously updated during the analysis, according to the modal shapes and participation factors derived through eigen-values analysis at each step. It provides the accurate method for evaluating the inelastic seismic response of structures. The response spectrum required for this type of analysis was extracted from the Indian seismic code (IS 1893 2002).

Step 3 Construct a force-displacement (pushover) relationship in each principal direction of building response.

Pushover curves usually represent the resistance of the structure when deformed into the inelastic range. These curves can be used to identify the beginning of structural yielding, as well as the displacement for each collapse is expected to occur. The plotting of maximum base shear resisted by the different building structures in both directions (X and Y) during non-linear analyses is plotted in Fig. 7.

Step 4 Approximate the force-displacement relationships into idealized piece wise linear representations that include the reference control points for use as input parameters for the SPO2IDA tool.

Fig. 6 An example of 3-D model adopted for non-linear analysis of Nepalese RC building structure

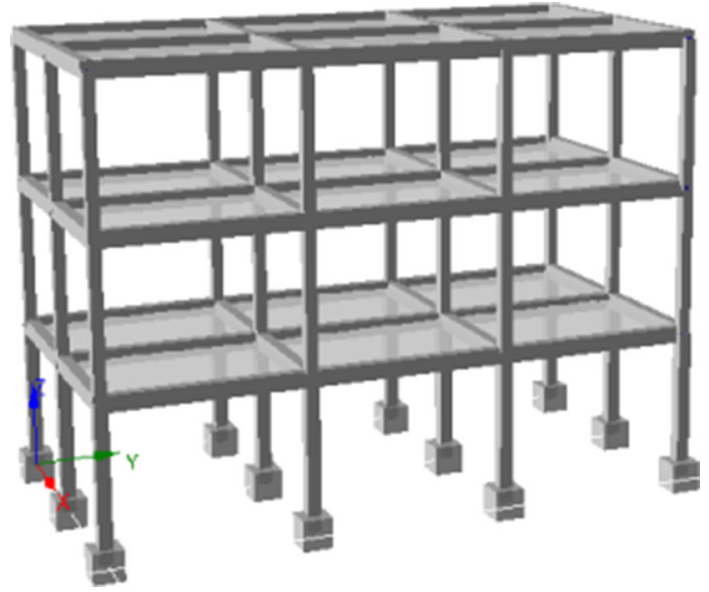


The force displacement curve obtained in step 3 is now idealized into strength reduction factor, $\mathrm{R}\left(\mathrm{Sa} / \mathrm{Sa}_{\mathrm{y}}\right)$ versus ductility, $\mu\left(\Delta_{\mathrm{u}} / \Delta_{\mathrm{y}}\right)$, which are the input parameters for the SPO2IDA tool. For idealization of pushover curve, the time period at yielding $\left(\mathrm{T}_{\mathrm{y}}\right)$ can be extracted from the capacity curves $\left(\mathrm{T}_{\mathrm{y}}=2 \pi \sqrt{\mathrm{Sd}_{y} / \mathrm{Sa}_{y}}\right)$ or through the employment of simplified formulae (e.g. Crowley and Pinho 2004, 2006). The spectral acceleration (Sa) and spectral displacement (Sd) is calculated using the ATC-40 procedure (ATC-40 1996). During the conversion of static pushover curve, the influence of static pushover curve on the dynamic behaviour can be studied through backbone curve. The backbone curve is composed of up to four segments as shown in Fig. 8. A full quadrilinear backbone starts elastically, yields at ductility $\mu=1$ and hardens at a slope $a_{h} \in(0,1)$ up to ductility $\mu_{\mathrm{c}} \in(1,+\infty)$. Furthermore, it turns negative at a slope $\mathrm{a}_{\mathrm{c}} \in[-\infty, 0)$, however it revived at $\mu_{\mathrm{r}}=\mu_{\mathrm{c}}+\left(1-\mathrm{r}+\left(\mu_{\mathrm{c}}-1\right) \mathrm{a}_{\mathrm{h}}\right) / \mathrm{a}_{\mathrm{c}} \mathrm{l}$ by a residual plateau of height $\mathrm{r} \in[0,1]$ only to fracture and drop to zero strength at $\mu_{\mathrm{f}} \in[1,+\infty)$. By suitably varying the five parameters, $a_{h}, \mu_{c}, a_{c}, r$ and $\mu_{f}$, almost any (bilinear, trilinear or quadrilinear) shape of the SPO curve can be easily matched (Vamvatsikos and Cornell 2006).

Step 5 Execute the SPO2IDA tool and extract the median and standard deviation of each limit state (moderate damage, extensive damage, and collapse).

It is an important step to execute the SPO2IDA tool and extract the median and standard deviation of each damage state. The damage state criteria are in accordance with the methods discussed in Sect. 2.4.1. The SPO2IDA tool provides a direct connection between the static curve and the results of incremental dynamic analysis (Vamvatsikos and Cornell 2006). The results for each limit state (i.e. moderate damage, extensive damage, and collapse) are summarized into their 16, 50 and $84 \%$ fractile IDA curves (see Fig. 9).

Step 6 Computing of the fragility curves based on the median values and corresponding dispersion values for each damage state.

Finally, a set of fragility curves has been developed according to each damage criterion as discussed in Sect. 2.4. Each fragility function was assumed to follow a lognormal distribution, with mean $(\mu)$ and standard deviation $(\sigma)$. The mean $(\mu)$ and standard deviation $(\sigma)$ per damage state for each building type in terms of spectral acceleration at the yield period of vibration ( $\mathrm{T} y$ ) is calculated in accordance with step 5 . Each fragility functions has been combined with a consequence model to produce a
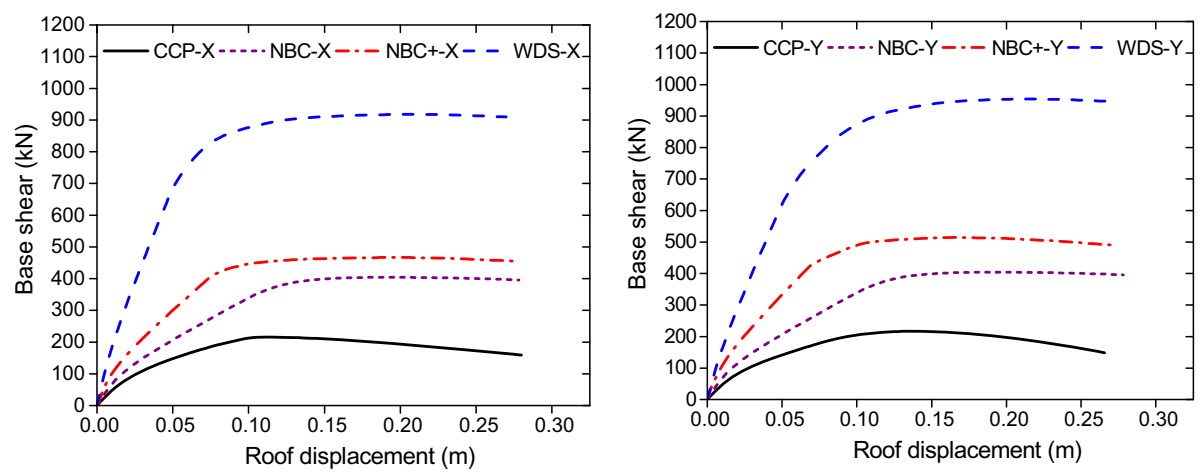

Fig. 7 Pushover curves for Nepalese RC buildings in X and Y direction of loadings respectively 


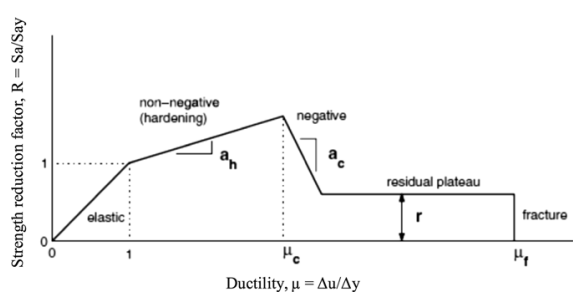

(a)

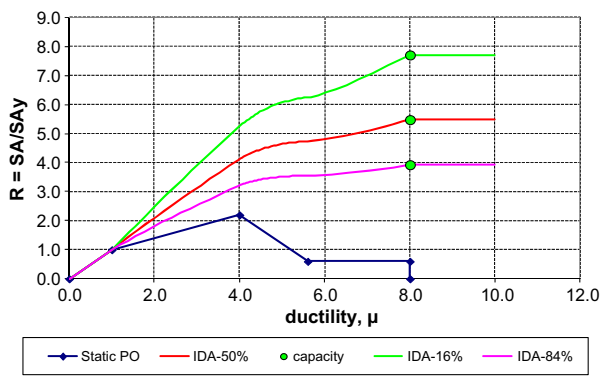

(b)

Fig. 8 a The backbone curve and its five controlling parameters and $\mathbf{b}$ force-displacement relationships for use as input parameters for the SPO2IDA tool

vulnerability model (see Sect. 2.4 .3 for additional details). The results demonstrate a high vulnerability for the adobe buildings; low vulnerability for the NBC+, WDS and wooden buildings; and an intermediate seismic vulnerability for the brick and stone buildings with cement mortar. The adobe buildings have the higher mean value for the lognormal distribution. It is due to the fact that these buildings collect various structural types such as: stone and adobe, stone and brick in mud, brick in mud and brick in cement. The intensity measure adopted in this study for Adobe/BM/BC is PGA, whilst spectral acceleration at the yielding period for remaining building typologies. Silva et al. (2014b) also addresses the similar issue in his study. The mean and standard deviation of the individual fragility functions are shown in Tables 9 and 10 and the resulting fragility curves are presented in Figs. 10, 11, 12 and 13.

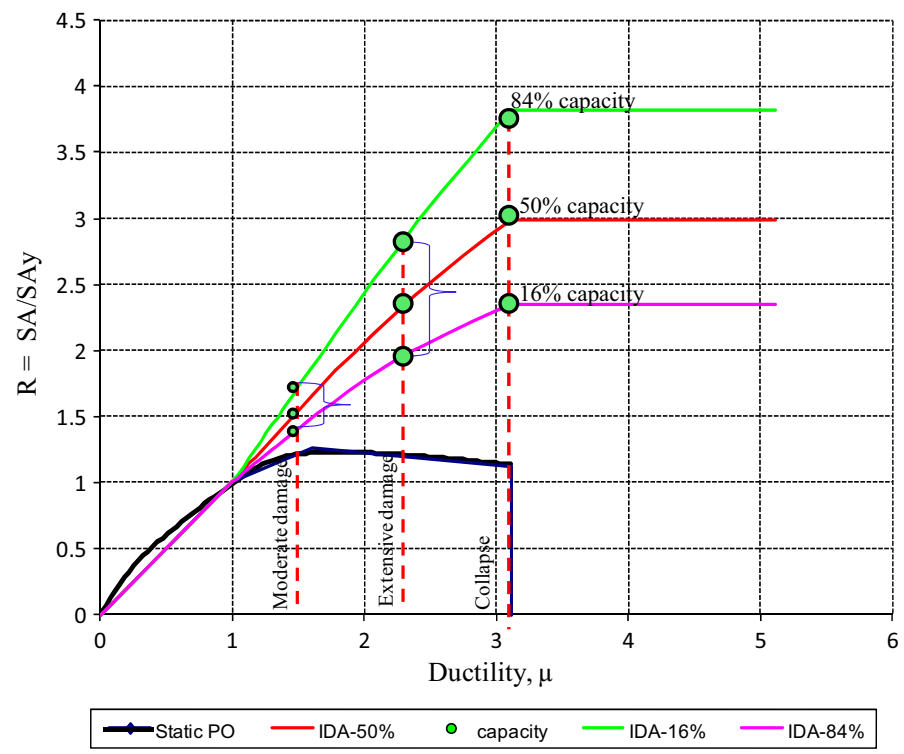

Fig. 9 The conversion of SPO2IDA for moderate damage, extensive damage and collapse 


\subsubsection{Evaluation of consequence models}

Consequence models can be used to convert a set of fragility curves into a vulnerability function. In this process, the percentage of buildings in each damage state is computed at each intensity measure level, and multiplied by the respective damage ratio, obtaining in this manner a loss ratio for each level of peak ground acceleration or spectral acceleration. As indicated in the literature, the consequence models developed for Turkey, California, and Portugal were different (see Fig. 14). All these models have different damage scales and each damage ratio might be influenced not just by the level of damage in the structure, but also by the local policy. The consequence model used in the development of the vulnerability model for the Nepalese RC building stock is presented in Table 11 and the resulting vulnerability functions for the building types in Kathmandu Valley are presented in Figs. 15, 16 and 17.

\subsection{Site effects}

Site conditions play a major role in establishing the damage potential for incoming seismic waves from major earthquakes. Damage patterns in Mexico City after the 1985 Michoacan earthquake demonstrated conclusively the significant effects of local site conditions on seismic response of the ground. The bed rock motions were amplified about five times. In the 1989 Loma Prieta earthquake, major damage occurred on soft soil sites in the San Francisco-Oakland region where the spectral accelerations were amplified two to four times over adjacent rock sites (Housner 1989), and caused severe damage. Amplification of amplitudes of soil particle motion from vertically propagating shear waves occurring from bed rock depends upon the geotechnical properties of overburden soil. The soil types, porewater pressure, and the level of water table are other significant site parameters. All these evidence clearly indicates that seismic design should incorporate the amplification effects of local soil conditions. To account for this shaking amplification effect, the average shear wave velocity in the top $30 \mathrm{~m}$ of a site (Vs30) is commonly used as the classifying parameter. The National Earthquake Hazards Reduction Program (NEHRP) has defined five soil types (namely A, B, C, D, and E) based on their shear-wave velocity. This site classification according to NEHRP (BSSC 2001) is shown in Table 12. The site effect in this study is considered according to Vs30 values in the Kathmandu Valley. The soil map associated with Vs30 value extracted from the USGS Vs30 database is presented in Fig. 18.

Table 9 The mean $(\mu)$ and standard deviation $(\sigma)$ per damage state for each building typology in terms of spectral acceleration at the yielding period (Ty)

\begin{tabular}{|c|c|c|c|c|c|c|c|}
\hline \multirow[t]{2}{*}{ Building typology } & \multirow[t]{2}{*}{$\mathrm{T}(\mathrm{s})$} & \multicolumn{2}{|c|}{ Moderate damage } & \multicolumn{2}{|c|}{ Extensive damage } & \multicolumn{2}{|c|}{ Collapse } \\
\hline & & $(\mu)$ & $(\sigma)$ & $(\mu)$ & $(\sigma)$ & $(\mu)$ & $(\sigma)$ \\
\hline $\mathrm{CCP}$ & 0.29 & -1.39 & 0.50 & -0.34 & 0.40 & 0.20 & 0.45 \\
\hline NBC & 0.27 & -1.05 & 0.47 & -0.16 & 0.38 & 0.30 & 0.41 \\
\hline $\mathrm{NBC}+$ & 0.23 & -0.80 & 0.48 & 0.00 & 0.35 & 0.45 & 0.38 \\
\hline WDS & 0.18 & -0.56 & 0.52 & 0.15 & 0.34 & 0.55 & 0.40 \\
\hline
\end{tabular}


Table 10 The mean $(\mu)$ and standard deviation $(\sigma)$ per damage state for each building typology in terms of peak ground acceleration

\begin{tabular}{|c|c|c|c|c|c|c|}
\hline \multirow[t]{2}{*}{ Building typology } & \multicolumn{2}{|c|}{ Moderate damage } & \multicolumn{2}{|c|}{ Extensive damage } & \multicolumn{2}{|c|}{ Collapse } \\
\hline & $(\mu)$ & $(\sigma)$ & $(\mu)$ & $(\sigma)$ & $(\mu)$ & $(\sigma)$ \\
\hline Adobe & -3.22 & 0.65 & -1.99 & 0.77 & -1.45 & 0.64 \\
\hline BM & -2.14 & 0.72 & -1.66 & 0.72 & -1.05 & 0.66 \\
\hline $\mathrm{BC}$ & -1.82 & 0.68 & -1.06 & 0.67 & -0.62 & 0.72 \\
\hline
\end{tabular}

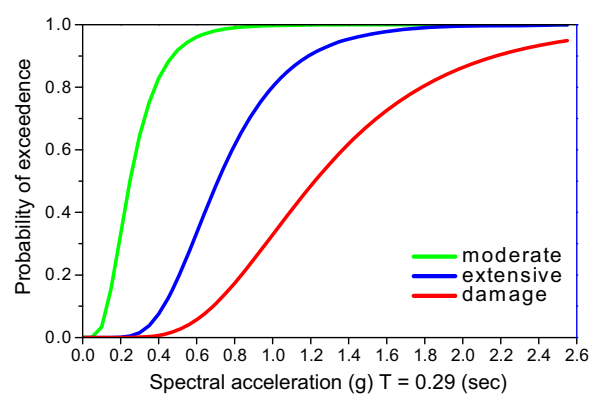

(a)

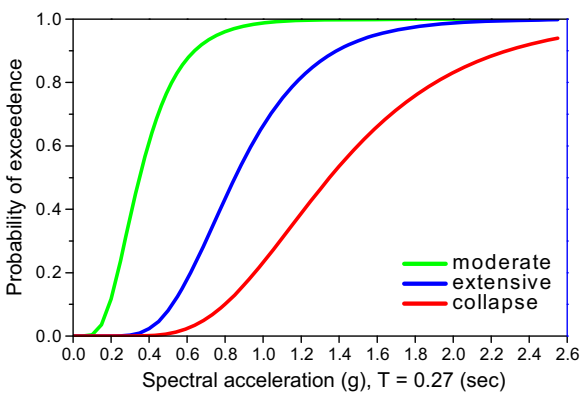

(b)

Fig. 10 Fragility models for a CCP and b NBC structures

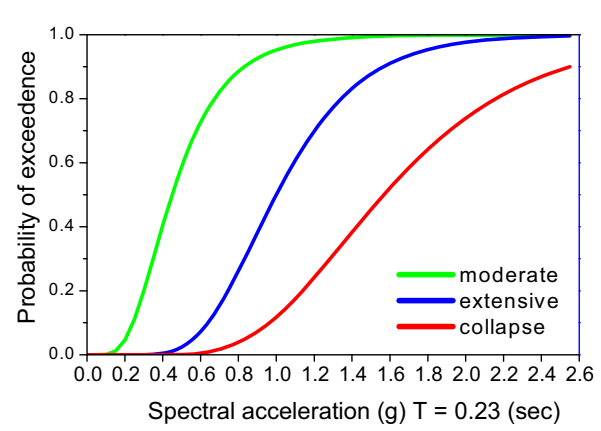

(a)

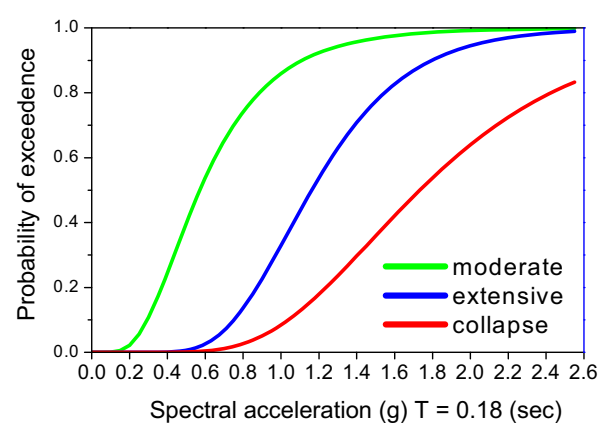

(b)

Fig. 11 Fragility models for a NBC+ and b WDS structures

\section{Computational tools}

The earthquake loss in Kathmandu Valley is estimated using the OpenQuake-engine (Silva et al. 2014c; Pagani et al. 2014). This tool is an open-source software written in the python programming language for calculating seismic hazard and risk from single sites to large regions. The engine has two scientific libraries (oq-hazardlib and oq-risklib) for hazard and risk computations. It is free, publically accessible, and is currently hosted on GitHub (https://github.com/gem/oq-engine). The OpenQuake-engine is being tested by several institutions and research projects in the world for the calculation of seismic hazard and 


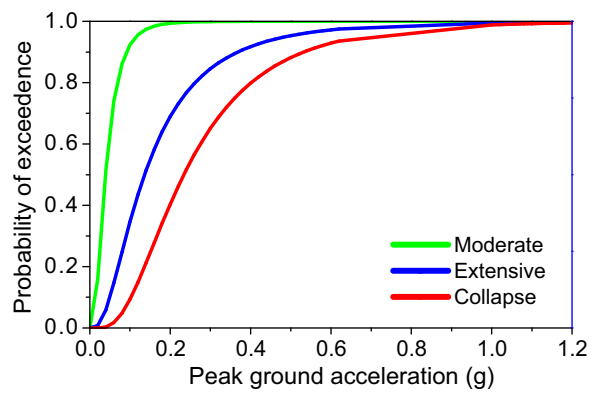

(a)

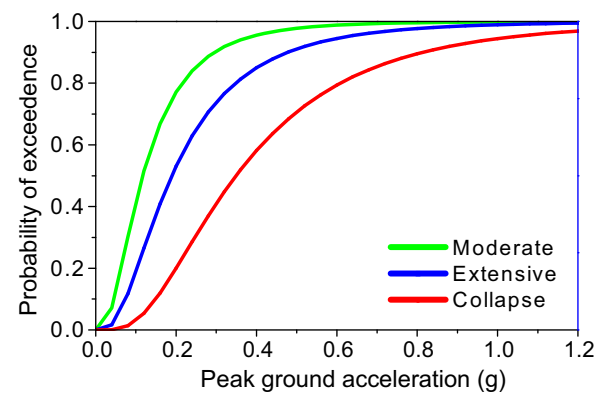

(b)

Fig. 12 Fragility models for a adobe and $\mathbf{b}$ brick/stone with mud mortar buildings

Fig. 13 Fragility model for brick/stone with cement mortar buildings

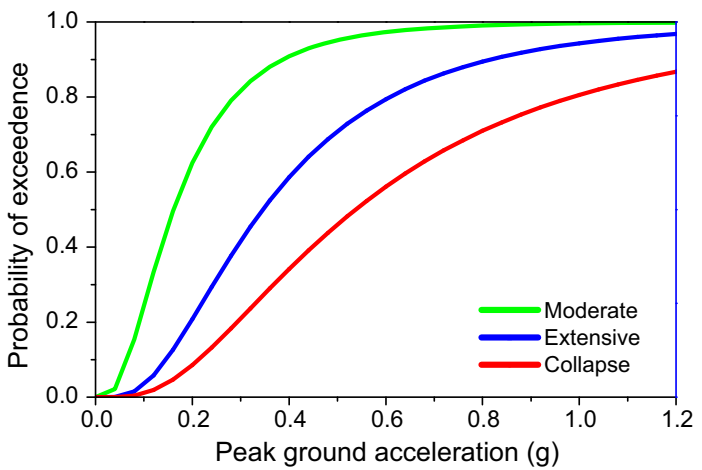

(a)

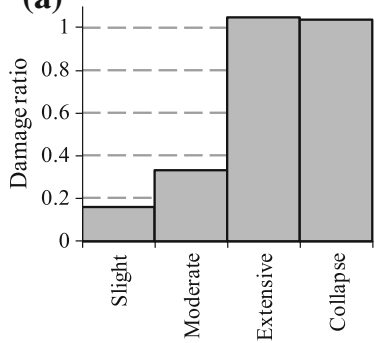

(b)

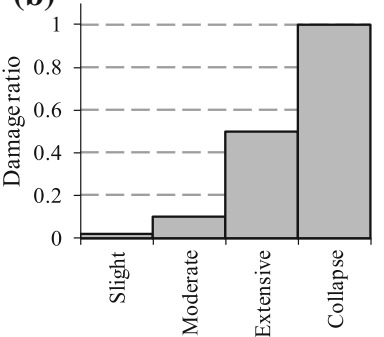

(c)

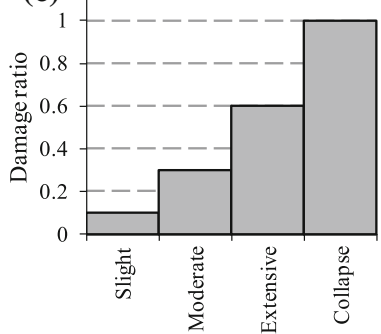

Fig. 14 Consequence model for a Turkey (Bal et al. 2008), b California (FEMA-443 2003) and c Portugal (Silva et al. 2014b)

risk. In this section, the median ground motion field in terms of peak ground acceleration for a region around the fault rupture is presented. The ward level damage distribution, collapse, and loss map of buildings in each municipality are also presented in the following sections.

\subsection{Scenario damage calculator}

The scenario damage calculator is used to estimate the distribution of building damage due to a single earthquake, for a spatially distributed building portfolio. In this context, a finite 
Table 11 Consequence model used in the development of the vulnerability model for the Nepalese building stock
Damage state

Damage ratio

Moderate damage

Extensive damage

0.60

Collapse
Fig. 15 Vulnerability functions for adobe, brick/stone with mud mortar, and brick/stone with cement mortar buildings

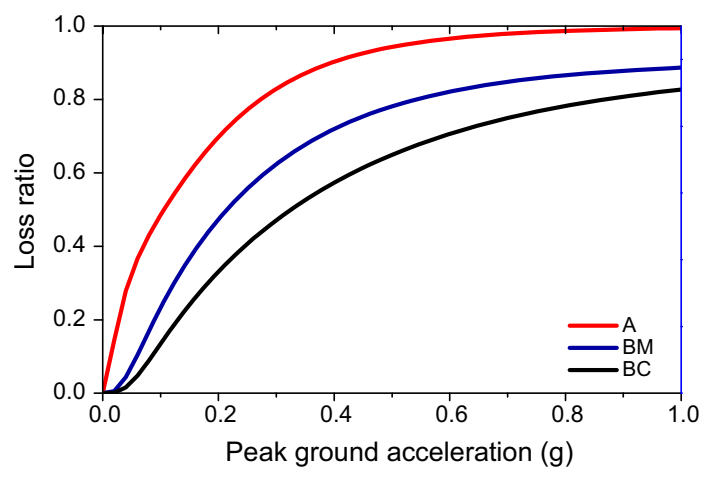

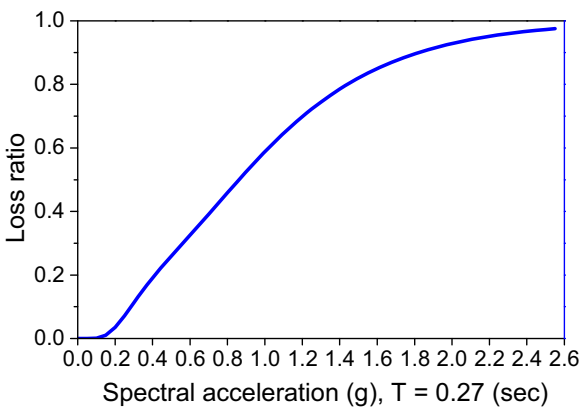

Fig. 16 Vulnerability functions for CCP and NBC building structures respectively

earthquake rupture must be used to derive sets of ground motion fields. In this calculator, each ground motion field is combined with a fragility model, in order to compute the fractions of buildings in each damage state. These fractions are calculated based on the difference in probabilities of exceedance between consecutive limit state curves at a given intensity measure level. This process is repeated for each ground motion field, leading to a list of fractions for each asset. These results can then be multiplied by the respective number of buildings in order to obtain the absolute building damage distribution.

\subsection{Scenario risk calculator}

The scenario risk calculator is used for computing losses and loss statistics from a single event for a collection of assets, given a set of ground motion fields. The input ground- 

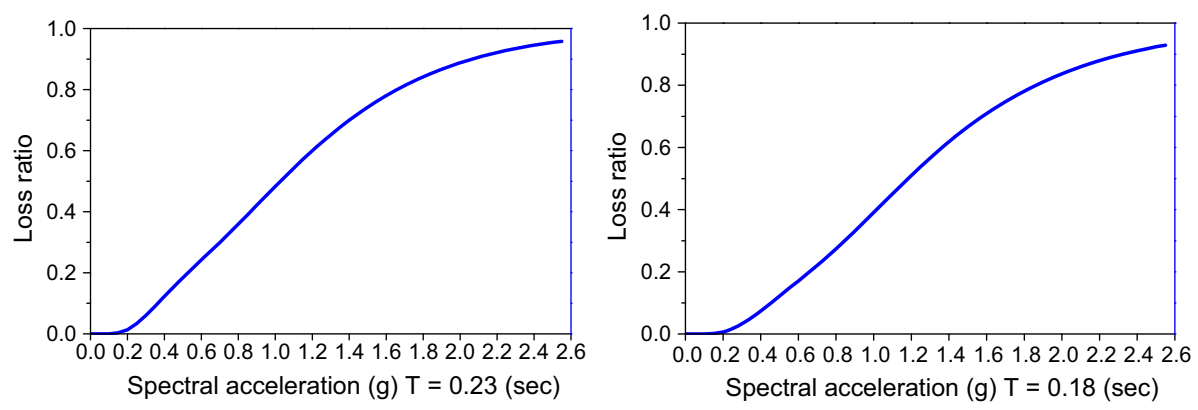

Fig. 17 Vulnerability functions for NBC+ and WDS building structures respectively

Table 12 Site classification according to NEHRP-USA (BSSC 2001)

\begin{tabular}{lll}
\hline Site class & Range of $\mathrm{V}_{30}(\mathrm{~km} / \mathrm{s})$ & Description \\
\hline $\mathrm{A}$ & $\mathrm{Vs} 30>1.5$ & $\begin{array}{c}\text { Includes unweathered intrusive igneous rock } \\
\mathrm{B}\end{array}$ \\
$0.76<\mathrm{Vs} 30 \leq 1.5$ & $\begin{array}{c}\text { Includes volcanics, most Mesozoic bedrock, and some } \\
\text { Franciscan bedrock }\end{array}$ \\
$\mathrm{C}$ & $0.36<\mathrm{Vs} 30 \leq 0.76$ & $\begin{array}{c}\text { Includes some Quaternary sands, sandstones and mudstones } \\
\text { Includes some Quaternary muds, sands, gravels, silts and } \\
\text { mud. Significant amplification of shaking by these soils } \\
\text { is generally expected }\end{array}$ \\
$\mathrm{E}$ & $0.18<\mathrm{Vs} 30 \leq 0.36$ & $\begin{array}{c}\text { Includes water-saturated mud and artificial fill. The strongest } \\
\text { amplification of shaking due is expected for this soil type }\end{array}$ \\
\hline
\end{tabular}

motion fields can be calculated with oq-hazardlib or by external software; in either case they need to be stored in the OpenQuake engine database. With the use of the oq-hazardlib, these ground-motion fields can be calculated either with or without the spatial correlation of the ground motion residuals. For each ground motion field, the intensity measure level at a given site is combined with a vulnerability function, from which a loss ratio is randomly sampled, for each asset contained in the exposure model. The loss ratios that are sampled for assets of a given taxonomy classification at different locations can be considered to be independent, fully correlated, or correlated with a specific correlation coefficient. Using these results, the mean and standard deviation of the loss ratios across all ground motion fields can be calculated. Loss ratios can be converted into ground-up losses by being multiplied by the cost of the asset given in the exposure model (Silva et al. 2014c).

\section{Analysis and interpretation of results}

\subsection{Ground motion field for earthquake scenarios}

The result of the ground motion field is based on the four possible earthquakes scenario in Nepal as discussed in Sect. 2.1. Three ground motion prediction equations proposed by: (a) Campbell and Bozorgnia (2008), (b) Boore and Atkinson (2008), and (c) Chiou et al. (2008) are employed for the computation of ground motion field, considering Nepal as a 
Fig. 18 Vs30 values for the soil in Kathmandu Valley

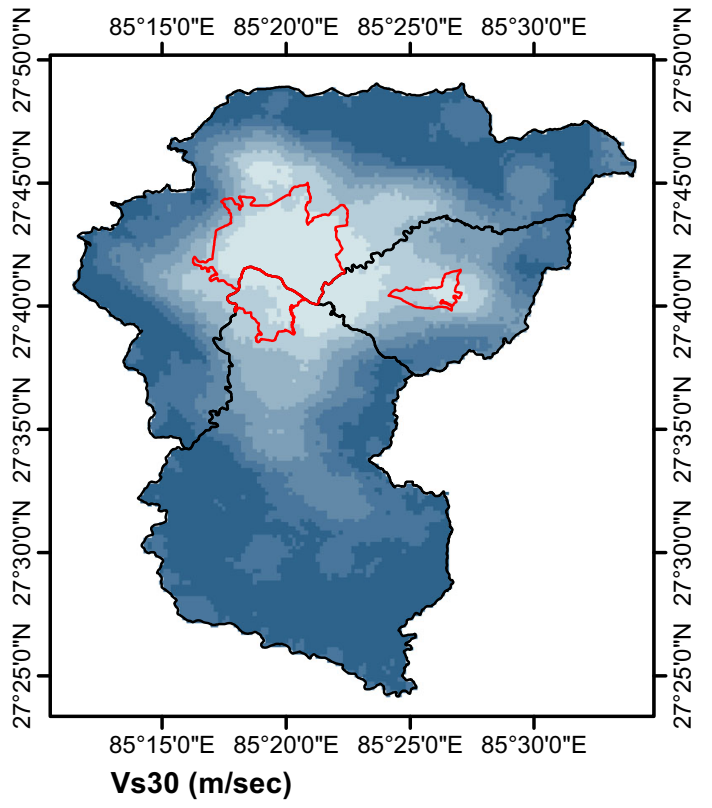

$\begin{array}{lllllll}330 & 397 & 480 & 571 & 654 & 713 & 760\end{array}$

shallow crustal tectonically active region. The spatial distribution of acceleration in the region of interest considering the aforementioned ground motion prediction equations is presented in Table 13.

\subsection{Damage distributions}

The damage distributions for each building type are determined using the OpenQuakeengine. This output is comprised of a set of damage nodes for which the amount of buildings in each damage state is described. The OpenQuake-engine provides a damage distribution per building type (amount of buildings in each damage state within the same building class) or the total damage distribution (sum of all the buildings in each damage state).

As previously mentioned, the structural damage to Nepalese buildings is classified into four groups: (a) no damage, (b) moderate damage, (c) extensive damage, and (d) collapse. As shown in Tables 14, 15 and 16 with respect to mean number of buildings in each damage state, three different damage patterns were observed in the four earthquake scenarios. The first scenario (EQ1) yields very low damage levels. The second and third scenarios (EQ2 and EQ3) led to intermediate damage levels. The fourth scenario (EQ4) presents much higher levels of damage. The mean and standard deviation of building damage was based on the results from the three ground motion predication equations mentioned in Sect. 4.1. From Figs. 19, 20 and 21, it can be observed that about $36.4 \%$ of adobe buildings collapsed in BMC due to earthquake scenario 4. The amount is limited to 33.6 and $28.1 \%$ in LSMC and $\mathrm{KMC}$, respectively. There is a remarkable collapse rate in $\mathrm{BM}, \mathrm{BC}$, and CCP buildings. From these results, it is also possible to observe that the 
Table 13 Ground motion field for earthquake scenarios in Nepal

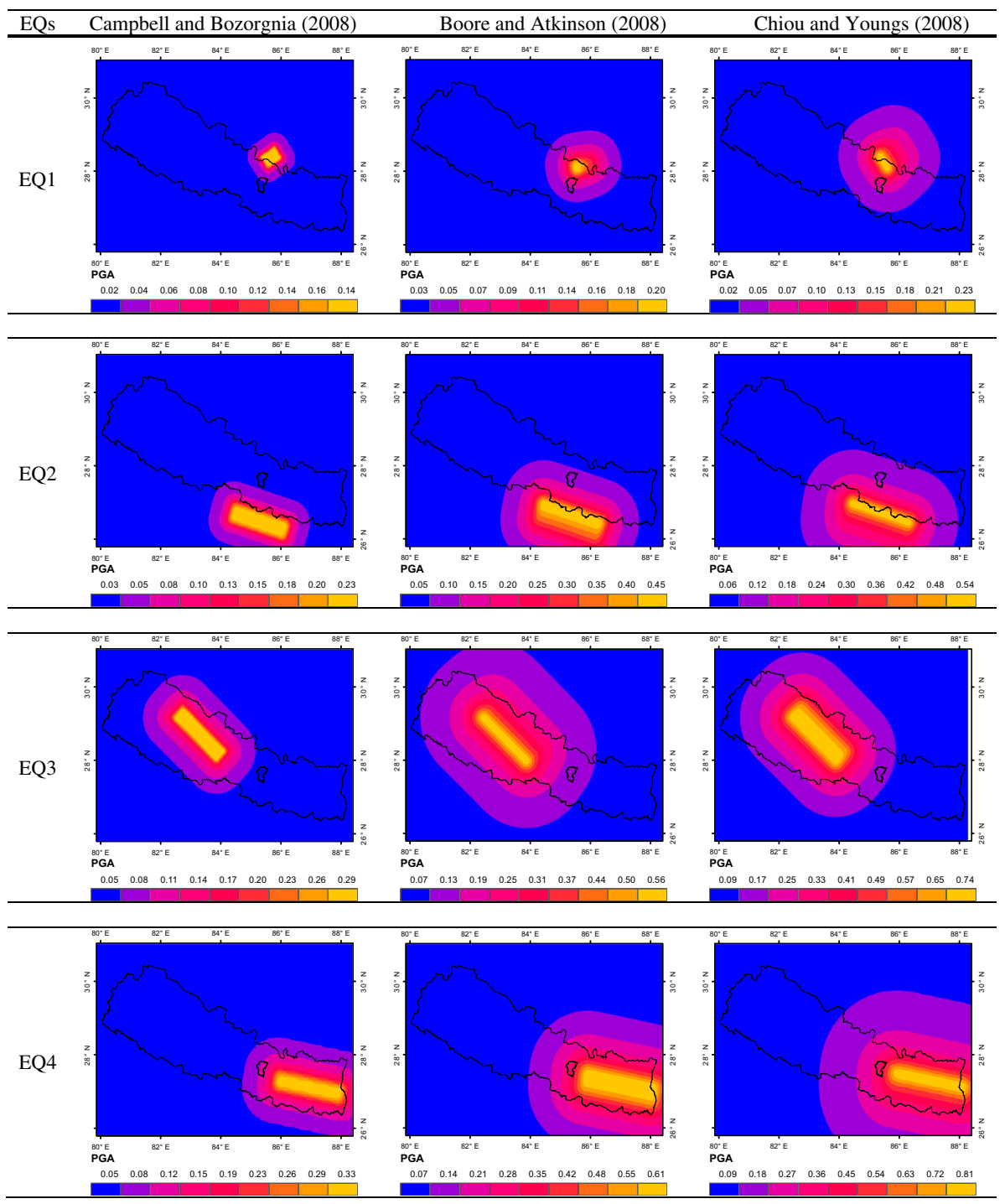

earthquake scenario EQ4 led to the highest number of collapsed buildings. The amount is $14.9 \%$ in BMC, $12.2 \%$ in LSMC and $9.7 \%$ in KMC. On the other hand, earthquake scenario EQ1 results minimal damage. The collapse of buildings is limited to $1.1 \%$ in BMC, $1.0 \%$ in LSMC and $0.8 \%$ in KMC. Earthquake scenarios EQ2 and EQ3 resulted in intermediate building damage.

These results indicate that building damage highly depends on the vulnerability class in the study area. The adobe buildings have higher probability of collapse compared to other building types, followed by brick in mud and brick in cement mortar buildings. Regarding 
Table 14 Distribution of total building damage in Kathmandu Metropolitan City

\begin{tabular}{|c|c|c|c|c|c|c|c|c|}
\hline \multirow[t]{2}{*}{ Damage state } & \multicolumn{2}{|l|}{ EQ1 } & \multicolumn{2}{|l|}{ EQ2 } & \multicolumn{2}{|l|}{ EQ3 } & \multicolumn{2}{|l|}{ EQ4 } \\
\hline & Mean & SD & Mean & SD & Mean & SD & Mean & SD \\
\hline No damage & 217,256 & 15,280 & 209,216 & 18,044 & 180,003 & 23,578 & 67,001 & 25,888 \\
\hline Moderate damage & 29,170 & 10,288 & 34,929 & 12,871 & 45,692 & 15,064 & 111,534 & 17,045 \\
\hline Extensive damage & 5859 & 4902 & 7828 & 6594 & 20,779 & 11,007 & 51,038 & 14,550 \\
\hline Collapse & 2031 & 3209 & 2341 & 3559 & 7844 & 9466 & 24,744 & 23,072 \\
\hline
\end{tabular}

Table 15 Distribution of total building damage in Lalitpur Sub-Metropolitan City

\begin{tabular}{|c|c|c|c|c|c|c|c|c|}
\hline \multirow[t]{2}{*}{ Damage state } & \multicolumn{2}{|l|}{ EQ1 } & \multicolumn{2}{|l|}{ EQ2 } & \multicolumn{2}{|l|}{ EQ3 } & \multicolumn{2}{|l|}{ EQ4 } \\
\hline & Mean & SD & Mean & SD & Mean & SD & Mean & SD \\
\hline No damage & 46,329 & 3773 & 44,666 & 5200 & 38,034 & 6334 & 13,732 & 6865 \\
\hline Moderate damage & 6398 & 2680 & 7540 & 3663 & 10,097 & 4159 & 22,986 & 4679 \\
\hline Extensive damage & 1328 & 1281 & 1774 & 1977 & 4447 & 3046 & 11,229 & 4134 \\
\hline Collapse & 523 & 816 & 599 & 1112 & 2002 & 2615 & 6632 & 6212 \\
\hline
\end{tabular}

Table 16 Distribution of total building damage in Bhaktapur Municipality

\begin{tabular}{|c|c|c|c|c|c|c|c|c|}
\hline \multirow[t]{2}{*}{ Damage state } & \multicolumn{2}{|l|}{ EQ1 } & \multicolumn{2}{|l|}{ EQ2 } & \multicolumn{2}{|l|}{ EQ3 } & \multicolumn{2}{|l|}{ EQ4 } \\
\hline & Mean & SD & Mean & SD & Mean & SD & Mean & $\mathrm{SD}$ \\
\hline No damage & 14,947 & 2041 & 14,400 & 2084 & 12,239 & 2325 & 4941 & 2058 \\
\hline Moderate damage & 2059 & 1310 & 2425 & 1239 & 3219 & 1599 & 6420 & 1501 \\
\hline Extensive damage & 445 & 756 & 590 & 827 & 1448 & 1276 & 3656 & 1587 \\
\hline Collapse & 192 & 482 & 227 & 637 & 736 & 1172 & 2626 & 2127 \\
\hline
\end{tabular}

RC buildings, the damage levels to be expected from a selected scenario seem to be reflecting the high vulnerability of buildings before Nepal Building Codes were introduced. The deficiency of structural design is highly observed in CCP structure. The percentage of damages is higher in BMC due to the local site conditions. The damage levels given in the selected scenarios should be taken as indicative and can only be used as a rough estimate of the expected damage.

\subsection{Economic loss map}

The ward level distribution of economic loss map as a result of the four scenario earthquakes in Kathmandu Metropolitan City, Latipur Sub-Metropolitan and Bhaktapur Municipality is presented in Fig. 22. The economic loss due to earthquakes scenario EQ1, EQ2, EQ3 and EQ4 in Bhaktapur Municipality is 20.25, 23.93, 45.37, and 161.63 million Euros, respectively. The amount is increased by 69.80, 74.21, 143.03, and 289.35 million Euros respectively in Lalitpur Sub-Metropolitan City. The economic loss is maximum in Kathmandu Metropolitan City. The cost is 254.47, 306.67, 556.59, and 972.87 million 


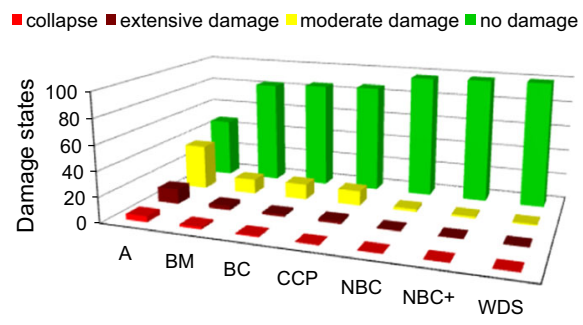

Building types

(a)

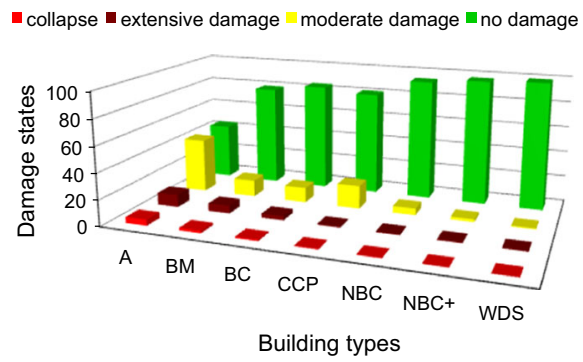

(b)

Fig. 19 Building damage for earthquake scenarios a EQ1 and b EQ2

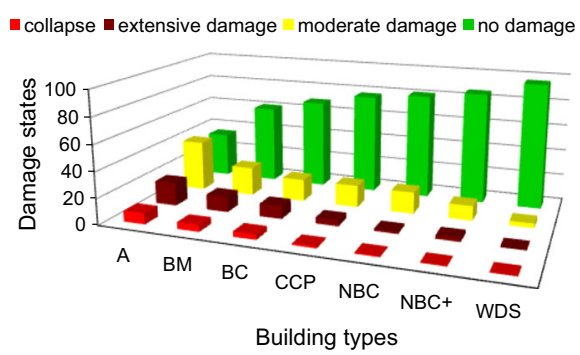

(a)

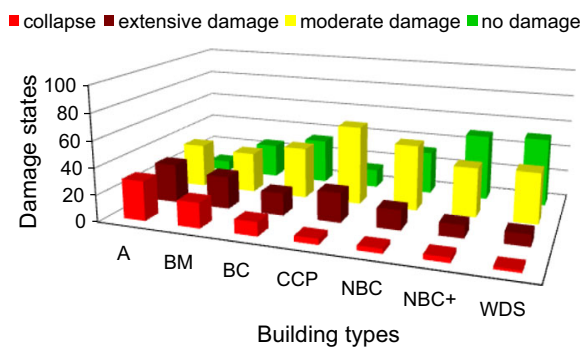

(b)

Fig. 20 Building damage for earthquake scenarios a EQ3 and b EQ4

Euros respectively for scenario EQ1, EQ2, EQ3 and EQ4, respectively. These losses follow the comparable trends to the observed loss in Spitak (Armenia) (Chatelaine et al. 1999).

\section{Conclusions}

The rapid urban development in Kathmandu Valley has lead to an increase in the exposure levels of the urban vulnerability. Due to the steadily increasing population with improper land-use planning, inappropriate construction techniques and inadequate infrastructure systems, associated with an existing high seismic hazard level, Kathmandu is one of the cities with the highest seismic risk in the south Asian region. Considering these facts, this study explores the current situation of earthquake consequences in three municipalities located within the Kathmandu Valley.

In this paper, the median ground motion field was calculated for four earthquakes scenario, and the spatial distribution of acceleration around the fault trace indicates that earthquakes scenario EQ1, EQ2, EQ3, and EQ4 predict a maximum peak ground acceleration of $0.23,0.54,0.74$, and $0.81 \mathrm{~g}$, respectively. Such values are well beyond the necessary ground shaking to cause widespread damage in the region.

Regarding the damage distribution, three damage patterns are observed in the four earthquakes scenario. The scenario EQ1 yields low damage levels. The maximum damage is observed in the earthquake scenario EQ4. The result also shows that about $36.4 \%$ of adobe buildings would collapse in BMC due to EQ4. The collapse of adobe building is limited to 33.6 and $28.1 \%$ in LSMC and $\mathrm{KMC}$, respectively. There is a remarkable 


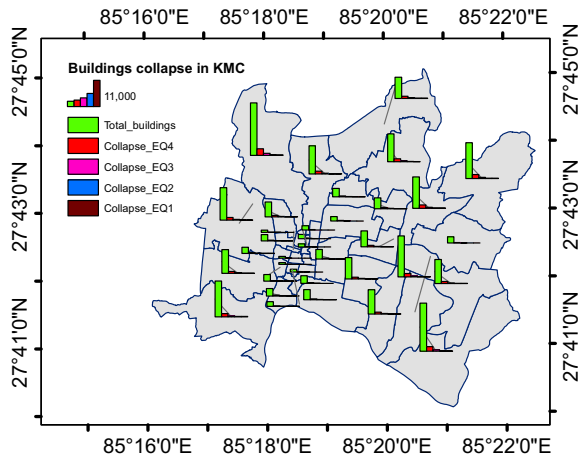

(a)

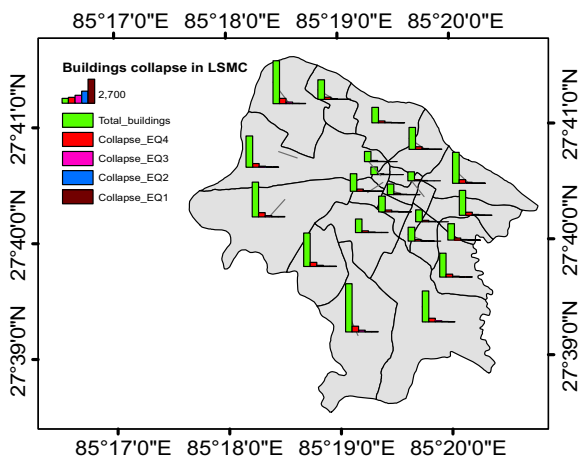

(b)

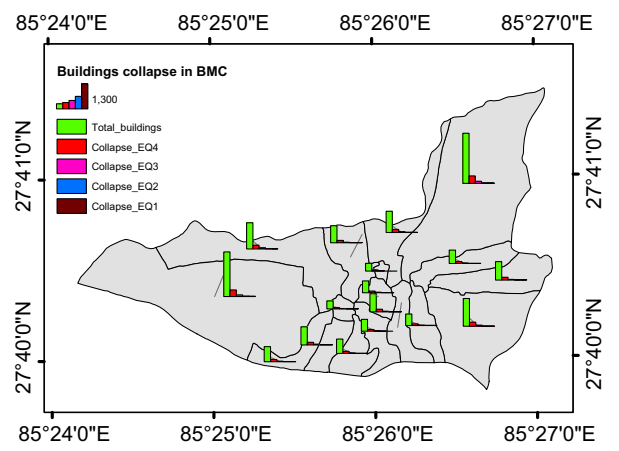

(c)

Fig. 21 Ward level distribution of building collapse in a KMC, b LSMC and BMC

collapse rate in brick with mud mortar, brick in cement mortar and current construction practices buildings. The level of buildings collapse due to earthquake scenario EQ4 is $14.9 \%$ in BMC, $12.2 \%$ in LSMC and $9.7 \%$ in KMC. The overall building collapse in Kathmandu Valley (BMC, KMC and LSMC) for EQ1, EQ2, EQ3 and EQ4 are 0.8, 1.0, 3.2 and $10.4 \%$, respectively.

From the aforementioned discussion, it can be concluded that vulnerability factors play a prominent role for building damage in the selected earthquakes scenario. As expected, adobe building type has higher damage ratio compared to other buildings. Brick in mud and brick in cement mortar buildings have intermediate damage ratio. The current construction practice building has higher damage ratio among other RC buildings. Furthermore, reinforced concrete buildings constructed before the introduction of the Nepal Building Code have higher vulnerability.

The economic loss due to earthquakes scenario EQ1, EQ2, EQ3, and EQ4 in Bhaktapur Municipality is $20.25,23.93,45.37$, and 161.63 million Euros, respectively. The amount is 69.80, 74.21, 143.03, and 289.35 million Euros in Lalitpur Sub-Metropolitan City. The economic loss is higher in Kathmandu Metropolitan City. The cost is 254.47, 306.67, 556.59, and 972.87 million Euros respectively for an earthquake EQ1, EQ2, EQ3 and EQ4.

From these alarming levels of loss and damage, it is important to investigate in risk mitigation action. These can include: 


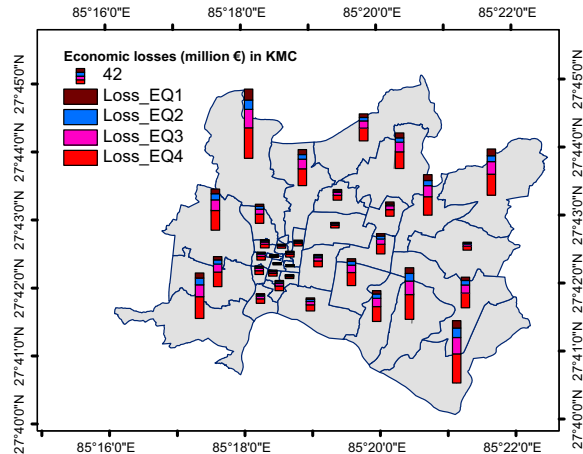

(a)

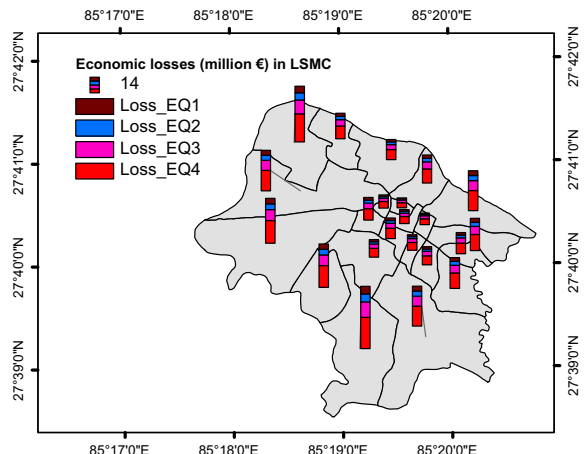

(b)

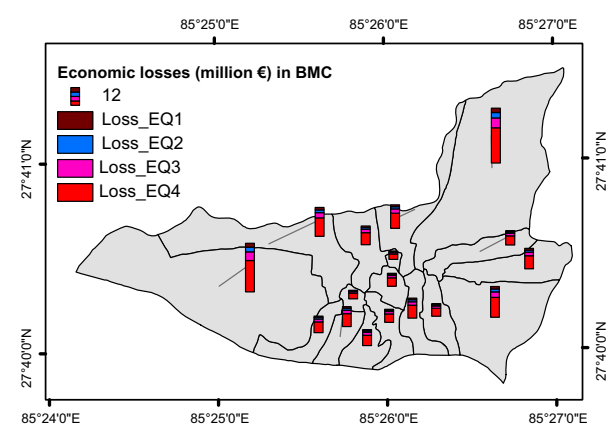

(c)

Fig. 22 Ward level distribution of economic loss in a KMC, b LSMC and $\mathbf{c}$ BMC

- Upgrading of Nepal buildings codes;

- Strengthening of design and construction regulations;

- Implementation of land use planning;

- Increasing the level of preparedness of disaster and rising societal awareness of earthquake risk.

Acknowledgments This research investigation is supported by the Eurasian University Network for International Cooperation in Earthquake (EU-NICE), through a fellowship for Ph.D. research of the first author. This support is gratefully acknowledged.

\section{References}

Akkar S, Sucuglu H, Yakut A (2005) Displacement-based fragility functions for low and mid-rise ordinary concrete buildings. Earthq Spectra 21(4):901-927

Ambraseys N, Douglas J (2004) Magnitude calibration of north Indian earthquakes. Geophys J Int 159(1):165-206

Antoniou S, Pinho R (2004) Development and verification of a displacement based adaptive pushover procedure. J Earthq Eng 8(5):643-661

Antoniou S, Pinho R (2006) Development and verification of a displacement based adaptive pushover procedure. J Earthq Eng 8(5):643-661 
Applied Technology Council (1985) Earthquake damage evaluation data for California. ATC-13, Redwood City

Bal I, Crowley H, Pinho R, Gaulay F (2008) Detailed assessment of structural characteristics of Turkish RC building stock for loss assessment models. Soil Dyn Earthq Eng 28:914-932

Barbat A, Moya Y, Canas J (1996) Damage scenarios simulation for seismic risk assessment in urban zones. Earthq Spectra 21(4):901-927

Bilham R (2001) Slow tilt reversal of the Lesser Himalaya between 1862 and 1992 at $78^{\circ} \mathrm{E}$, and bounds to the southeast rupture of the 1905 Kangara earthquake. Geophys J Int 144:713-728

Bilham R, Bodin P, Jackson M (1995) Entertaining a great earthquake in western Nepal: historic inactivity and geodetic tests for the present state of strain. J Nepal Geol Soc 11(1):73-78

Bommer JJ, Spence R, Erdik M, Tabuchi S, Aydinoglu N, Booth E, Re DD, Pterken D (2002) Development of an earthquake model for Turkish Catastrophe Insurance. J Seismolog 6:431-446

Boore DM, Atkinson GM (2008) Ground-motion prediction equations for the average horizontal component of PGA, PGV, and 5\%-Damped PSA at spectral periods between 0.01 and $10.0 \mathrm{~s}$. Earthq Spectra 24(1):99-138

BSSC (2001) NEHRP recommended Part 1: provisions prepared by the Building Seismic Safety Council for the Federal Emergency Management Agency (FEMA 368), Washington DC, USA, 2001

Campbell KW, Bozorgnia Y (2008) NGA ground motion model for the geometric mean horizontal component of PGA, PGV, PGD and $5 \%$ damped linear elastic response spectra for periods ranging from 0.01 to 10 s. Earthq Spectra 24(1):139-171

Central Bureau of Statistics (CBS) (2012) National Population and Housing Census 2011. National Report, National Planning Commission Secretariat, Central Bureau of Statistics, Kathmamdu, Nepal

Chamlagain D, Hayashi D (2004) Numerical simulation of fault development along NE-SW Himalayan profile in Nepal. J Nepal Geol Soc 29:1-11

Chamlagain D, Hayashi D (2007) Neotectonic fault analysis by 2D finite-element modeling for studying the Himalayan fold-and-thrust belt in Nepal. J Asian Earth Sci 29:473-489

Chamlagain D, Kumahara Y, Nakata T, Upreti BN (2000) Active faults of Nepal Himalaya with references to Himalayan frontal fault and their neotectonic significance. In: Proceeding of QUCTEHR, Kumaon University, India, pp 124-125

Chatelaine JL, Tucker B, Guillier B, Kaneko F, Yepes H, Fernandez J, Valverde J, Hoefer G, Souris M, Duperier E, Yamada T, Bustamante G, Villacis C (1999) Earthquake risk management pilot project in Quito, Ecuador. GeoJournal 49:185-196

Chaulagain H, Rodrigues H, Jara J, Spacone E, Varum H (2013) Seismic response of current RC buildings in Nepal: a comparative analysis of different design/construction. Eng Struct 49:284-294

Chiou BS, Robert R, Youngs RR (2008) An NGA model for the average horizontal component of peak ground motion and response spectra. Earthq Spectra 24(1):173-215

Colombi M, Borzi B, Crowley H, Onida M, Meroni F, Pinho R (2008) Deriving vulnerability curves using Italian earthquake damage data. Bull Earthq Eng 6(3):485-504

Crowley H, Pinho R (2004) Period-height relationship for existing European reinforced concrete buildings. J Earthq Eng 8:93-119

Crowley H, Pinho R (2006) Simplified equations for estimating the period of vibration of existing buildings. In: Proceedings of the 1st European conference on earthquake engineering and seismology, Geneva, Switzerland, Paper No. 1122

Crowley H, Borzi B, Pinho R, Colombi M, Ondida M (2008) Comparison of two mechanics-based methods for simplified structural analysis in vulnerability assessment. Adv Civ Eng. http://www.hindawi.com/ journals/ace/2008/438379/cta/

Dixit A (2004) Promoting Safer Buildings in Nepal. Proceedings of the13th world conference on earthquake engineering, Paper No. 1717

Dumova-Jovanoska E (2000) Fragility curves for reinforced concrete structures in Scopje reigon. Soil Dyn Earthq Eng 19(6):455-466

Dunn JA, Auden JB, Gosh ANM, Roy SC (1939) The Bihar-Nepal earthquake of 1934. Mem Geol Survey India 73:391

Elnashai AS, Elghazouli AY (1993) Performance of composite steel/concrete members under earthquake loading, Part I: analytical model. Earthq Eng Struct Dyn 22:315-345

Erberic MA, Elnashai AS (2004) Vulnerability analysis of flat-slab structures. Eng Struct 26:937-948

Erdik M, Durukal E (2008) Earthquake risk and its mitigation in Istanbul. Nat Hazards 44:181-197

FEMA, NIBS (1999) Earthquake loss estimation methodology-HAZUS 99. Federal Emergency Management Agency and National Institute of Buildings Sciences, Washington DC, USA

FEMA-443 (2003) HAZUS-MH technical manual. Federal Emergency Management Agency, Washington DC, USA 
Filippou FC, Popov EP, Bertero VV (1983) Effects of bond deterioration on hysteretic behaviour of reinforced concrete joints, Report EERC 83-19, Earthquake Engineering Research Center, University of California, Berkeley

Gaspari M (2009) Assessment of the earthquake vulnerability of low-rise buildings in Greece with application in Pylos town (Messinia prefecture). Master of Science thesis, Department of Geology and Geoenvironment, National Kapodistrian University of Athens, Cross-Institutional Post-Graduate Programme on the Prevention and Management of Natural Catastrophes, May 2009

Grünthal G (1998) European Macroseismic Scale 1998 (EMS-98) (1998). Cahiers du Centre Européen de Géodynamique et de Séismologie 15, Centre Européen de Géodynamique et de Séismologie, Luxembourg

Gupta H, Gahalaut VK (2014) Seismotectonics and large earthquake generation in the Himalaya region. Gondwana Res 25:204-213

Gutenberg B, Richter CF (1954) Seismicity of the earth and associated phenomena. Princeton University Press, Princeton, p 273

Hancilar U, Durukal E, Franco G, Deodatis G, Erdik M, Smyth, A (2006) Probabilistic vulnerability analysis: an application to a typical school building in Istanbul. In: Proceedings of the 1st European conference on earthquake engineering and seismology, Geneva, Switzerland

Housner GW (1989) Competing against time. Report to Governor Deukmejian of California, Governor's Board of Inquiry on the 1989 Loma Prieta Earthquake

IS 13920 (1993) Indian standard ductile detailing of reinforced concrete structures subjected to seismic force. Bureau of Indian Standards

IS 1893 (Part1) (2002) Indian standard criteria for earthquake resistant design of structures, Bureau of Indian Standards, 5th Revision. Bureau of Indian Standards, ManakBhavan, 9 Bahadur Shah ZafarMarg, New Delhi

JICA (2002) The study on Earthquake disaster mitigation in the Kathmandu Valley, Kingdom of Nepal, Japan International Cooperation Agency and the Ministry of Home Affairs of Nepal, vols I, II and III

Kappos AJ, Panagopopulos G, Penelis G (2006) A hybrid method for the vulnerability assessment of R/C and URM buildings. Bull Earthq Eng 4:391-413

Khattrai KN (1987) Great earthquakes, seismicity gaps and potential for earthquake disaster along the Himalaya plate boundary. Tectonophysics 138:79-92

Khattri KN, Wyss M (1978) Precursory variation of seismicity rate in the Assam ares, India. Geology 6:685-688

Kircil MS, Polat Z (2006) Fragility analysis of mid-rise R/C frame buildings. Eng Struct 28(9):1335-1345

Kostov M, Kaneva A, Vaseva M, Stefanov N (2007) An advanced approach to earthquake risk scenarios of Sofia. In: Proceedings of the 8th Pacific conference on earthquake engineering, 5-7 Demember, Singapore

Lava J, Avouac JP (2000) Active folding of fluvial terraces across the Siwaliks Hills, Himalayas of central Nepal. J Geophys Res 105:5735-5770

Madas P, Elnashai AS (1992) A new passive confinement model for the analysis of concrete structures subjected to cyclic and transient dynamic loading. Earthq Eng Struct Dyn 21(5):409-431

Mander JB, Priestley MJN, Park R (1988) Theoretical stress-strain model for confined concrete. J Struct Eng 114(8):1804-1826

Martinez-Rueda JE (1997) Energy dissipation devices for seismic upgrading of RC structures, Ph.D. thesis, Imperial College, University of London, London, UK

Menegotto M, Pinto PE (1973) Method of analysis for cyclically loaded RC plane frames including changes in geometry and non-elastic behaviour of elements under combined normal force and bending, In: Symposium on the resistance and ultimate deformability of structures acted on by well defined repeated loads. International Association for Bridge and Structural Engineering, Zurich, pp 15-22

Middlemiss CS (1910) The Kangra earthquake of 4th April, 1905. Mem Geol Surv India 37:1-409

Molnar P, Pandey MR (1988) Ruture zone of great earthquakes in Himalayan region. Earth Planetary Science 98:61-70

Nakata T (1982) A photogrammetric study on active faults in the Nepal Himalayas. J Nepal Geol Soc 2:67-80

NBC 205:1994 (1994) Nepal National Buildings Code. HMG/Ministry of Housing and Physical Planning, Department of Building

Ni J, Barazangi M (1984) Seismotectonics of Himalayan collision zone: geometry of the under thrusting Indian plate beneath the Himalaya. J Geophys Res 89:1147-1163

Pagani M, Monelli D, Weatherill G, Danciu L, Crowley H, Silva V, Henshaw P, Butler L, Nastasi M, Panzeri L, Simionato M, Vigano D (2014) OpenQuake engine: an open hazard (and risk) software for the global earthquake model. Seismol Res Lett 85(3):692-702 
Pandey MR, Molnar P (1988) The distrubition of intensity of the Bihar-Nepal earthquake 15 January 1934 and bounds of the extent of the rupture zone. J Nepal Geol Soc 5:22-44

Pandey MR, Tandukar RP, Avouac JP, Lave J, Massot JP (1995) Interseismic strain accumulation on the Himalayan crustal ramp (Nepal). Geophys Res Lett 22(7):751-754

Pandey MR, Tandukar RP, Avouac JP, Vergne J, Heritier T (1999) Seismotectonics of Nepal Himalaya from a local seismic network. J Asian Earth Sci 17:703-712

Rana BJB (1935) Nepal ko Maha Bhukampa (Great earthquake of Nepal) Jorganesh press, Kathmandu

Rosetto T, Elnashai A (2005) A new analytical procedure for the derivation of displacement-based vulnerability curves for populations of RC structures. Eng Struct 27(3):397-409

Rota M, Penna A, Strobbia C (2008) Processing Italian damage data to derive typological fragility curves. Soil Dyn Earthq Eng 28:933-947

Satyabala SP, Gupta HK (1996) Is the quiescence of major earthquakes $(M \geq 7.5)$ since 1952 in the Himalaya and northeast India real? Bull Seismol Soc Am 86:1983-1986

SEAOC (1995) Vision 2000, performance based seismic engineering of buildings: conceptual framework, vol I and II. Structural Engineers Association of California, Sacramento

Sebber L, Armbruster J (1981) Great detachment earthquakes along the Himalayan arc and long-term forecasting. In: Simpson DW, Richards PG (eds), Earthquake prediction-an international review: Maurice Ewing Series American Geophysical Union, vol 4, 1st edn. American Geophysical Union, USA, pp 259-277

SeismoSoft (2006) A computer program for static and dynamic nonlinear analysis of framed structure. http://www.seismosoft.com

Shrestha B, Dixit AM (2008) Standard design for earthquake resistant buildings and aid to building code implementation in Nepal. In: Proceedings of the 14th world conference on earthquake engineering, Beijing, China

Silva V, Crowley H, Pinho R, Varum H (2014a) Seismic risk assessment for mainland Portugal. Bull Earthq Eng 13(2):429-457

Silva V, Crowley H, Pinho R, Varum H (2014b) Investigation of the characteristics of Portuguese regular moment-frame RC buildings and development of a vulnerability model. Bull Earthq Eng. doi:10.1007/ s10518-014-9669-y

Silva V, Crowley H, Pagani M, Monelli D, Pinho R (2014c) Development of the OpenQuake engine, the global earthquake model's open-source software for seismic risk assessment. Nat Hazards 72(3):1409-1427

UNDP (2010) Recommendatios for construction of Earthquake Safer Buildings-earthquake risk reduction and recovery preparedness programme for Nepal. UNDP/ERRRP-Project: NFP/07/010, Department of Urban Development and Building Construction, Babarmahal, Kathmandu

Vamvatsikos D, Cornell CA (2006) Direct estimation of the seismic demand and capacity of oscillators with multilinear static pushovers through Incremental dynamic analysis. Earthq Eng Struct Dyn 35(9):1097-1117

Wallace K, Bilham R, Gaur VK, Gahalaut V, Blume F (2005) Geodetic constraint of the 1905 Kangara earthquake and interseismic deformation 1846-2001. Geophys Res Lett 32:L15307. doi:10.1029/ 2005GL022906

Wyss M, Wiemer S (1999) How can one test the seismic gap hypothesis? The case of ruptures in the Aleutians. Pure appl Geophys 155:259-278 